\title{
Systematic Review/Meta-analysis
}

\section{Right Ventricular Outflow Tract Obstruction in Adults: A Systematic Review and Meta-analysis}

Yu Hao Zeng, MD, ${ }^{a}$ Alexander Calderone, MD, ${ }^{a}$ Nicolas Rousseau-Saine, MD, FRCPC,

Mahsa Elmi-Sarabi, PhD, ${ }^{a}$ Stéphanie Jarry, MSc, ${ }^{a}$ Étienne J. Couture, MD, FRCPC, ${ }^{b}$

Matthew P. Aldred, MBBS, FANZCA, ${ }^{a}$ Jean-Francois Dorval, MD, FRCPC,

Yoan Lamarche, MD, MSc, FRCSC, ${ }^{\mathrm{d}, \mathrm{e}}$ Lachlan F. Miles, MBBS, PhD, FANZCA, ${ }^{\mathrm{f}}$

William Beaubien-Souligny, MD, PhD, FRCPC, ${ }^{g}$ and André Y. Denault, MD, PhD, FRCPC ${ }^{a, e}$

${ }^{a}$ Department of Anesthesiology, Montreal Heart Institute, Université de Montréal, Montreal, Quebec, Canada

${ }^{b}$ Department of Anesthesiology and Department of Medicine, Division of Intensive Care Medicine, Quebec Heart \& Lung Institute, Quebec, Quebec, Canada

${ }^{c}$ Department of Cardiology, Montreal Heart Institute, Université de Montréal, Montreal, Quebec, Canada

${ }^{d}$ Department of Cardiac Surgery, Montreal Heart Institute, Université de Montréal, Montreal, Quebec, Canada

${ }^{e}$ Critical Care Division, Montreal Heart Institute, Université de Montréal, Montreal, Quebec, Canada

${ }^{f}$ Department of Critical Care, The University of Melbourne, Melbourne, Victoria, Australia and Department of Anaesthesia, Austin Health, Melbourne, Australia

${ }^{g}$ Department of Medicine, Nephrology Division, Centre Hospitalier de l'Université de Montréal, Montreal, Quebec, Canada

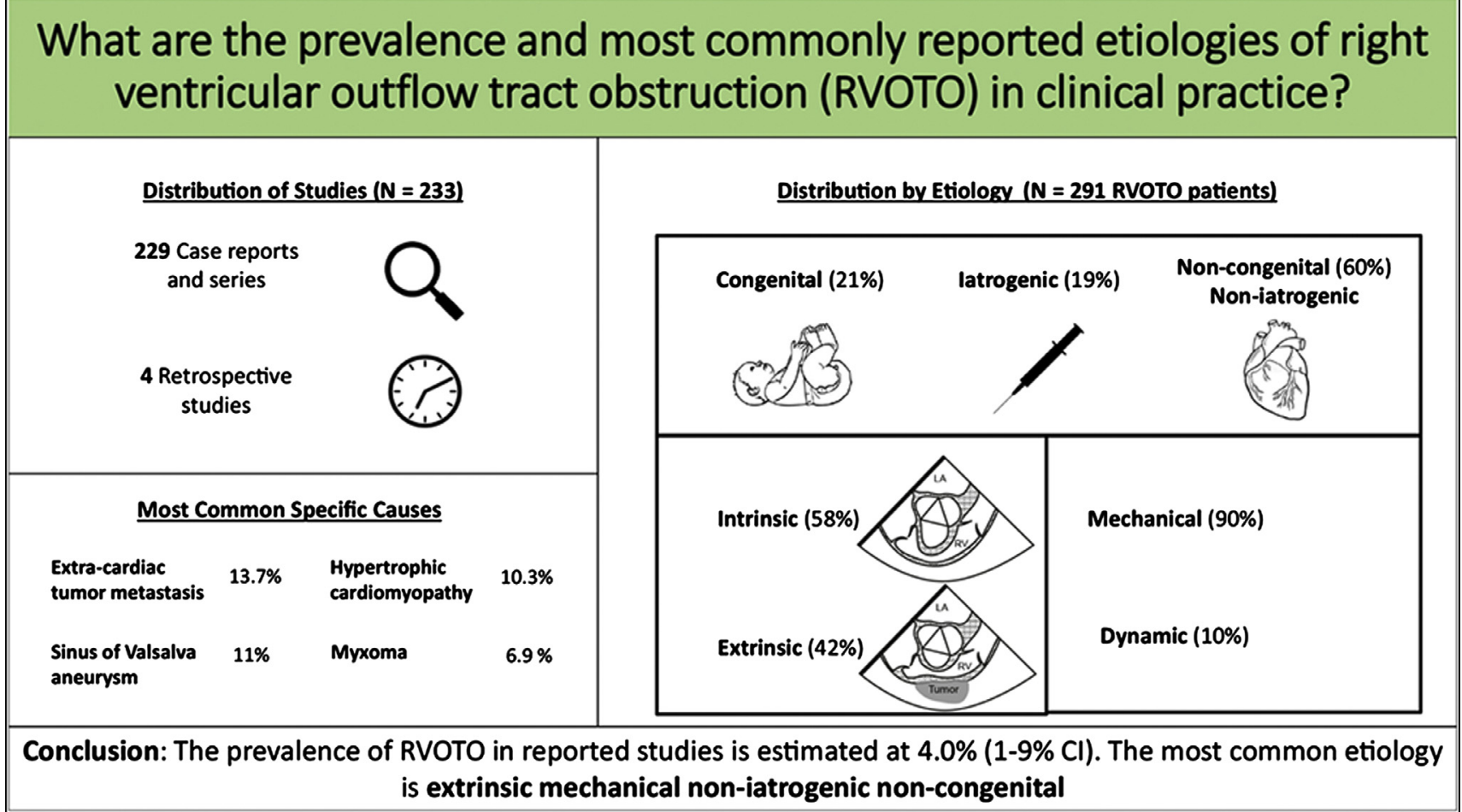




\section{ABSTRACT}

Background: Right ventricular outflow tract obstruction (RVOTO) is a cause of hemodynamic instability that can occur in several situations, including cardiac surgery, lung transplantation, and thoracic surgery, and in critically ill patients. The timely diagnosis of RVOTO is important because it requires specific considerations, including the adverse effects of positive inotropes, and depending on the etiology, the requirement for urgent surgical intervention.

Methods: The objective of this systematic review and meta-analysis was to determine the prevalence of RVOTO in adult patients, and the distribution of all reported cases by etiology.

Results: Of 233 available reports, there were 229 case reports or series, and 4 retrospective cohort studies, with one study also reporting a prospective cohort. Of 291 reported cases of RVOTO, 61 (21\%) were congenital, 56 (19\%) were iatrogenic, and 174 (60\%) were neither congenital nor iatrogenic (including intracardiac tumour). The mechanism of RVOTO was an intrinsic obstruction in 169 cases (58\%), and an extrinsic obstruction in 122 cases (42\%). A mechanical obstruction causing RVOTO was present in 262 cases (90\%), and 29 cases of dynamic RVOTO (10\%) were reported. In the 5 included cohorts, with a total of 1122 patients, the overall prevalence was estimated to be $4.0 \%$ (1\%-9\%).

Conclusions: RVOTO, though rare, remains clinically important, and therefore, multicentre studies are warranted to better understand the prevalence, causes, and consequences of RVOTO.

Right ventricular (RV) dysfunction is associated with significant morbidity and mortality, particularly in cardiac surgery. ${ }^{1-4}$ These associations could be related to several factors, including venous congestion and cardio-intestinal syndrome. ${ }^{5,8}$ An uncommon mechanism of RV dysfunction and elevated right atrial pressure is $\mathrm{RV}$ outflow tract obstruction (RVOTO). It is diagnosed by the presence of a systolic pressure gradient between the main pulmonary artery (PA) and the RV outflow tract (RVOT). This obstruction has been defined as hemodynamically significant when the maximal systolic pressure gradient between the RV and the PA is greater than $25 \mathrm{~mm} \mathrm{Hg}{ }^{7}$ This condition requires urgent treatment when it results in decreased end-organ perfusion from both reduced cardiac output and increased venous congestion.

The diagnosis can be made by imaging (computed tomography $[C T]$ or magnetic resonance), transthoracic echocardiography (TTE), transesophageal echocardiography (TEE), epicardial intraoperative echocardiography, or cardiac catheterization. It can be both diagnosed and monitored continuously using a PA catheter with an RV port capable of simultaneously transducing the RV and PA pressures. ${ }^{8}$ There are several etiologies of RVOTO, which can be classified according to their pathophysiological mechanism; some of these are congenital, ${ }^{9}$ whereas others are iatrogenic. ${ }^{10}$ The mechanism of RVOTO also can be differentiated depending on the location of the obstruction, whether intrinsic ${ }^{11}$ or extrinsic ${ }^{12}$ to the RVOT, and on the persistence of the phenomenon relative to the

\section{RÉSUMÉ}

Contexte : L'obstruction de la chambre de chasse du ventricule droit (OCCVD) est une cause d'instabilité hémodynamique qui peut survenir dans plusieurs situations, y compris une chirurgie cardiaque, une transplantation pulmonaire ou une chirurgie thoracique, ou encore chez des patients en phase critique. II est important que le diagnostic d'OCCVD soit posé rapidement, car d'une part cette affection exige la prise en compte d'éléments particuliers, y compris les effets indésirables des agents inotropes positifs et, d'autre part, en fonction de l'étiologie, une intervention chirurgicale d'urgence pourrait être nécessaire.

Méthodologie : L'objectif de cette revue systématique associée à une méta-analyse était de déterminer la prévalence de l'OCCVD chez les patients adultes ainsi que la distribution de tous les cas rapportés en fonction de leur étiologie.

Résultats : Sur les 233 rapports disponibles, on comptait 229 études ou séries de cas, et quatre études de cohortes rétrospectives, dont une qui présentait également les résultats d'une cohorte prospective. Sur 291 cas d'OCCVD rapportés, 61 (21\%) étaient d'origine congénitale, 56 (19\%) étaient d'origine iatrogène et 174 (60\%) avaient une origine qui n'était ni congénitale ni iatrogène (dont une tumeur intracardiaque). Le mécanisme de l'OCCVD était une obstruction intrinsèque dans 169 cas (58\%), et une obstruction extrinsèque dans 122 cas (42\%). Une obstruction mécanique causant l'OCCVD était présente dans 262 cas (90\%), et 29 cas d'OCCVD dynamique (10\%) ont été rapportés. Dans les 5 cohortes incluses, comptant au total 1122 patients, la prévalence globale était estimée à 4,0 \% (de $1 \%$ à $9 \%)$.

Conclusions : L'OCCVD, malgré sa rareté, n'en est pas moins importante sur le plan clinique; la réalisation d'études multicentriques serait donc justifiée pour permettre de mieux comprendre la prévalence, les causes et les conséquences de cette affection.

timing of the cardiac cycle (dynamic during systole or diastole only or persistent throughout the cardiac cycle). ${ }^{13}$

To our knowledge, no comprehensive review of the prevalence or etiology of RVOTO in adults has been published. We therefore performed a narrative review in order to answer important, related questions: (i) What is the prevalence of RVOTO in the adult population? (ii) What is the distribution of cases of RVOTO according to etiology? and (iii) How can we define RVOTO?

\section{Methods}

\section{Study eligibility and search strategy}

To be eligible for inclusion, articles had to report at least one case of RVOTO in adult patients and describe its etiology. Only full published reports in English or French were considered. Articles that represented a combination of both pediatric and adult populations were excluded if the authors did not specify the age of the patients with RVOTO.

Received for publication February 9, 2021. Accepted March 23, 2021.

Ethics Statement: No consent was required for this study.

Corresponding author: Dr André Y. Denault, Montreal Heart Institute, 5000 Belanger Street, Montreal, Quebec H1T 1C8, Canada. Tel.: +1-514 376-3330; fax: +1-514 376-1355.

E-mail: andre.denault@umontreal.ca

See page 1162 for disclosure information. 
Supravalvular and valvular causes of obstruction were excluded from the analysis, and only sub-valvular causes were cumulated. The articles were retrieved via a PubMed search (last accessed on August 15, 2020) with the following keywords: "RVOTO" or "right ventricle outflow tract obstruction" or "right ventricle outflow tract stenosis" with "cardiac surgery" and "adult" in [all fields] or medical subject headings. An advanced search was conducted from the initial simple search by manually modifying the medical subject heading terms to maximize the number of relevant studies found. The PubMed search query and results are detailed in Supplemental Appendix S1. Secondary sources were obtained by manually screening the bibliographies of all articles. Instances in which the primary and secondary sources were used as citations in other articles were examined individually to screen for additional articles.

\section{Data extraction}

The etiologies of RVOTO were divided into 3 categories: 1 , congenital-caused by a disease or physical abnormality that has been present since birth; 2, iatrogenic-caused by a medical intervention or procedure; 3 , non-congenital/non-iatrogenic-caused by a disease or physical abnormality that has not been present since birth and not caused by a medical intervention or procedure. Within each category, the obstruction was classified as either mechanical, if the dimensions of the RVOT remained constant during the cardiac cycle, or dynamic, if the dimensions of the RVOT changed during the cardiac cycle. The cause of obstruction was also classified according to its location. It was defined as "intrinsic" 11 if the origin of the RVOTO arose within the anatomic structure of the RVOT itself, as in hypertrophic cardiomyopathy. It was defined as "extrinsic" if the cause of RVOTO was not related to the normal anatomy of the RVOT, as in an aneurysm of the sinus of Valsalva whereby the RVOT was externally compressed. The number of patients with RVOTO, along with the diagnostic method and moment of diagnosis, were also extracted from each article.

The initial database search and classification of articles were performed by one of the authors (Y.Z.). The entire research methodology was redone a second time by another author (A. C.) in order to identify any discrepancies and articles that may have been missed by the initial review. Differences in etiology classification and in exclusion or inclusion of articles were flagged, and then reviewed by a third author (A.D.). Once these were resolved, a final review was performed by the second author (A.C.). Cohort studies were verified and validated by a fourth author (W.B.). The quality of the retrospective studies used in the meta-analysis was assessed using the National Heart, Lung, and Blood Institute Study Quality Assessment Tools.

\section{Analysis}

Data about the prevalence of RVOTO collected from cohort studies were used to conduct a meta-analysis of proportions using the arcsine transformation. Given that there was important clinical and methodological heterogeneity among studies, we calculated pooled proportions and 95\% confidence intervals (CIs) using a random effects model. We used inverse variance to weigh each study in the pooled analysis and assessed statistical heterogeneity using $\mathrm{I}^{2}$ values. We considered a $P$ value $<0.05$ to be statistically significant. A subgroup analysis was performed by grouping studies depending on whether they were designed to include only patients at high risk for RVOTO (special population) vs any type of surgery patients. We performed all analyses with $\mathrm{R}$ version 3.6.1 (R Core team, Vienna, Austria) using the metaprop command from the $\mathrm{R}$ package meta version $4.13 .^{14}$

\section{Results}

\section{Results from the literature search}

Our PubMed search identified a total of 1013 articles on human subjects written in English or French. Of the 1013 articles retrieved, 890 were excluded for one or more of the following reasons: there was no mention of the prevalence or etiology of RVOTO; the articles described an obstruction of either the left ventricular outflow tract or the RV inflow tract; the articles described cases of pulmonary stenosis or obstruction that occurred in a location outside of the RVOT; and the study subjects came from a pediatric population or a mixed adult-pediatric population in which differentiation was impossible.

Following the exclusion process, 124 primary articles in total were retained. A total of 109 articles were retrieved from the bibliographic examination of the 124 retained studies, as well as reverse citation of these primary and secondary sources, resulting in a total of 233 studies, summarized in Supplemental Table S1. ${ }^{10,15-246}$ Supplemental Figure S1 describes the search process in a flow diagram.

\section{Description of studies}

A total of 291 patients with RVOTO in 233 studies have been reported so far in the medical literature. These patients were retrieved from 209 case reports $(89.7 \%), 20$ case series (8.6\%), and 4 retrospective studies (1.7\%). All case reports and series described an etiology of RVOTO that fell within our predefined classification. All retrospective studies focused on the prevalence of RVOTO, and one report combined a retrospective and a prospective cohort. ${ }^{122}$ In these 4 retrospective studies, the populations consisted of a mix of adult and pediatric patients, but the adult cases were distinguished from the pediatric cases. $^{76,102,164,237}$

Table 1 summarizes the etiology distribution and mechanism of reported cases of RVOTO. A total of 174 cases (60\%) were non-congenital and non-iatrogenic; 61 (21\%) were congenital; and 56 (19\%) were iatrogenic. The mechanism of RVOTO was intrinsic in 169 cases (58\%) and extrinsic in 122 cases (42\%). A mechanical obstruction causing the RVOTO was present in 262 cases (90\%), and only 29 cases of dynamic RVOTO (10\%) were reported. The subcategories of each types are detailed in Supplemental Table S2.

The non-congenital and non-iatrogenic cases are summarized in Supplemental Table S3. As noted, most of this class of RVOTO cases were related to 71 (41\%) primary cardiac tumours, 40 (23\%) extracardiac tumours including metastasis or compression, or $32(18 \%)$ cases of 
Table 1. Etiology distribution and mechanism of reported right ventricular outflow tract obstruction cases $(n=291)$

\begin{tabular}{|c|c|c|c|c|c|c|}
\hline & \multicolumn{2}{|c|}{$\begin{array}{l}\text { Non-congenital and non-iatrogenic } \\
(\mathrm{n}=174 ; 60 \%)\end{array}$} & \multicolumn{2}{|c|}{$\begin{array}{c}\text { Congenital } \\
(\mathrm{n}=61 ; 21 \%)\end{array}$} & \multicolumn{2}{|c|}{$\begin{array}{c}\text { Iatrogenic } \\
(\mathrm{n}=56 ; 19 \%)\end{array}$} \\
\hline & Intrinsic & Extrinsic & Intrinsic & Extrinsic & Intrinsic & Extrinsic \\
\hline Mechanical(n = 262) & $76(43.7)$ & $94(54)$ & $58(95.1)$ & $1(1.6)$ & $9(16)$ & $24(42.9)$ \\
\hline Dynamic $(\mathrm{n}=29)$ & $3(1.7)$ & $1(0.6)$ & $2(3.3)$ & $0(0)$ & $21(38)$ & $2(3.6)$ \\
\hline
\end{tabular}

Values are $\mathrm{n}(\%)$.

sinus of Valsalva aneurysms (18\%). The most common primary cardiac tumours reported were myxomas and PA or trunk neoplasms, representing $28 \%$ and $25 \%$ of all primary tumours in reported cases, respectively. The most common extracardiac tumours reported were renal cell carcinoma, representing $12.5 \%$ of extracardiac tumour compressions.

Congenital cases are described in Supplemental Table S4. Of these 61 cases, 30 (49\%) were due to cases of hypertrophic cardiomyopathy, and $15(25 \%)$ were related to a doublechambered right ventricle.

The iatrogenic cases are summarized in Supplemental Table S5. The most common causes were dynamic systolic obliteration associated with vasoactive/ionotropic agent use during surgery in 11 patients, and RVOTO after lung transplantation in 9 patients. Dynamic RVOTO was observed in only 29 cases, much less frequently than mechanical obstruction. Eleven cases of obstruction were worsened by the administration of inotropes or vasoactive agents during surgery, ${ }^{122}$ and one occurred during the induction of anesthesia. ${ }^{23}$ Most of the other reported cases were observed after lung transplantation $(\mathrm{n}=9) .{ }^{5,61,65,67,70,108,142,231}$ Two cases occurred as a result of cardiac surgery complications, ${ }^{134,242}$ and one case resulted from a postoperative mediastinal hematoma. ${ }^{66} \mathrm{~A}$ single case could be attributed to cardiac catheterization, which iatrogenically precipitated infundibular muscular spasm in a patient with pulmonic stenosis and thus dynamic RVOTO. ${ }^{10}$ Six cases were secondary to structures in the heart causing dynamic obstruction solely during systole, with 2 attributed to myxomas, ${ }^{31,219} 2$ due to septal aneurysms, ${ }^{106,227}$ and another 2 due to double-chambered right ventricle muscle bundles. ${ }^{205}$

The most frequent overall causes of RVOTO irrespective of etiologic classification are summarized in Table 2. Extracardiac tumour metastasis or compression of the right ventricle was the most common cause found in our study, representing $13.7 \%$ of all cases described in this literature review. This cause was followed in frequency by sinus of Valsalva aneurysm (11\%), hypertrophic cardiomyopathy (10.3\%), myxoma (6.9\%), and PA/trunk neoplasm (6.2\%). Four reports were made of dual RVOTO and left ventricular outflow tract obstruction. ${ }^{91,96,133,193}$

\section{Definition of RVOTO and diagnostic technique}

In the majority of studies analyzed, TTE or TEE $(n=195)$ were part of the investigational workup for RVOTO. Cardiac catheterization $(\mathrm{n}=94)$ was the second most commonly used investigational modality. Most of the diagnoses were made preoperatively $(\mathrm{n}=187)$. The remaining diagnoses were made intraoperatively $(\mathrm{n}=10)$, during the immediate postoperative period or in the intensive care unit $(\mathrm{n}=10)$, as a contemporaneously distant postoperative diagnosis $(n=25)$. The majority of studies relied on multiple investigative modalities in order to properly establish the diagnosis of RVOTO $(\mathrm{n}=190)$. Overall, CT scan or CT angiography $(\mathrm{n}=79)$ were more commonly used than cardiac magnetic resonance imaging $(n=57)$ as complementary forms of investigation to provide confirmation of RVOTO or reveal the extent of the obstruction. In some instances, the investigative workup suggested the diagnosis, or the workup could not be performed and the diagnosis was confirmed on autopsy following the patient's death. $^{20,27,29,37,57,59,129,243}$ There were no predetermined echocardiographic diagnostic criteria across the studies. In one study, RVOTO is explicitly defined as a flow velocity of $>2.0 \mathrm{~m} / \mathrm{s}(16 \mathrm{~mm} \mathrm{Hg})$ on continuous wave Doppler TTE across the RVOT; ${ }^{102}$ however, this specific criterion is not universally mentioned in all studies. Intraoperatively, clinically significant RVOTO in the largest study was defined as a gradient $>25 \mathrm{~mm} \mathrm{Hg}$ between the RV and PA systolic pressures, as measured by a PA catheter. ${ }^{122}$

Table 2. Most-frequent overall reported causes of right ventricular outflow obstruction

\begin{tabular}{|c|c|}
\hline Etiology and references & $\begin{array}{c}\text { Cases, } \mathrm{n} \\
\text { (\% of total cases) }\end{array}$ \\
\hline Extracardiac tumour metastasis/compression: & $40(13.7)$ \\
\hline \multicolumn{2}{|l|}{$\begin{array}{l}19,23,27,29,32,37,40,45,49,52,54(3) \\
57,59(3), 62,69,79,80,89,90,97,98 \\
118,124,129,147,156,160,178,187 \\
206,213,216,224,233,234,240\end{array}$} \\
\hline Sinus of Valsalva aneurysm: & $32(11)$ \\
\hline \multicolumn{2}{|l|}{$\begin{array}{l}21,35,39,41,46,56,60(2), 76,81,100, \\
103,110,125,127,136,139,144,148, \\
153,172,179,180,191,192,194,201, \\
207,209,212,236,244\end{array}$} \\
\hline Hypertrophic cardiomyopathy: & $30(10.3)$ \\
\hline \multicolumn{2}{|l|}{$\begin{array}{l}51(4), 91,92,96,102(9), 128,133,152, \\
164(9), 193,241\end{array}$} \\
\hline Myxoma: & $20(6.9)$ \\
\hline \multicolumn{2}{|l|}{$\begin{array}{l}15,20,24,31,64,71,85,93,101,112 \\
116,131,149,159,162,167,182,188 \\
219,238\end{array}$} \\
\hline $\begin{array}{l}\text { Pulmonary artery/trunk neoplasm: } \\
\qquad 26(11), 104(2), 111,130,137,161,225\end{array}$ & $18(6.2)$ \\
\hline \multicolumn{2}{|l|}{$\begin{array}{l}88(3), 158(2), 164(2), 181,190,203,205 \\
(2), 214,228,245\end{array}$} \\
\hline $\begin{array}{l}\text { Dynamic systolic obliteration associated with } \\
\text { vasoactive agent use during surgery: }\end{array}$ & $11(3.8)$ \\
\hline $122(11)$ & \\
\hline
\end{tabular}

Parenthetical after reference number indicates number of cases within reference. 


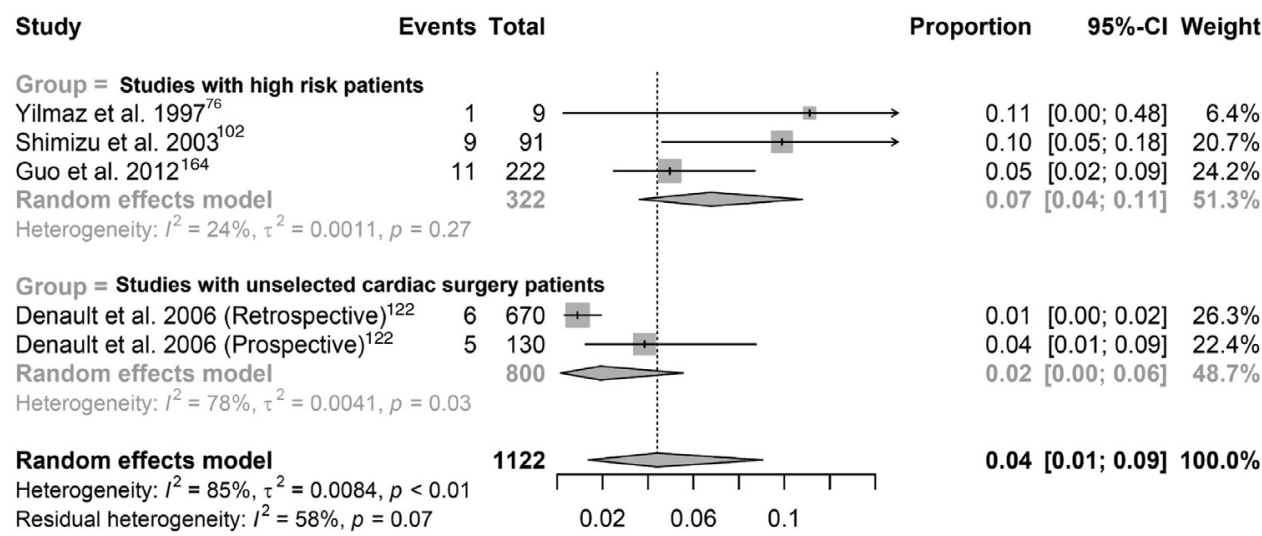

Figure 1. Prevalence of right ventricular outflow tract obstruction in the setting of cardiac surgery. Forest plot of the 4 included studies with 5 cohorts. The prevalence ranged from $1 \%$ to $11 \%$, depending on the studied population. Studies were separated based on whether or not they were performed on a specific population. In the 5 included cohorts with a total of 1122 patients, the overall prevalence was estimated to be $4.0 \%$ (confidence interval [Cl]: 1\%-9\%). Significant heterogeneity was observed in the included studies $\left(\mathrm{I}^{2}=85 \%\right)$.

\section{Prevalence of RVOTO}

The prevalence of RVOTO in patients under different conditions was determined in 5 cohorts, with a total number of 1122 patients (Supplemental Table S6). The estimated prevalence from these studies is $4 \%(1 \%-9 \%)$ with significant statistical heterogeneity $\left(\mathrm{I}^{2}=85 \%\right.$; Fig. 1$)$.

In the only study including unselected cardiac surgery patients and using continuous RV and PA pressure monitoring, Denault et al. reported an RVOTO prevalence of $0.9 \%$ in the retrospective cohort of 670 patients, and a prevalence of $3.8 \%$ in a prospective cohort of 130 patients. ${ }^{122}$ The pooled prevalence in these cohorts was 2\% (CI: 0\%-6\%), although significant statistical heterogeneity was found between these cohorts $\left(\mathrm{I}^{2}=78 \%\right)$.

The 3 remaining studies had smaller $\mathrm{n}$ values, which varied between 9 and 222, and showed the prevalence of RVOTO in particular populations, including patients who had an aneurysm of the sinus of Valsalva (11.1\%), ${ }^{76}$ patients with hypertrophic cardiomyopathy $(9.9 \%),{ }^{102}$ and patients undergoing corrective surgery for sinus of Valsalva aneurysm (5\%). ${ }^{164}$ The pooled prevalence in these cohorts, including patients at risk for RVOTO, was 7\% (CI: 4\%-11\%) with moderate statistical heterogeneity $\left(\mathrm{I}^{2}=24 \%\right)$.

\section{Methodological quality of studies}

The 236 studies included contained diverse methodologies and limitations. A retrospective methodology was used in 235 $(99.6 \%)$ studies, and only one study $(0.4 \%)$ used a prospective design exclusively. One of the retrospective studies contained a prospective cohort for validation. ${ }^{122}$ Most studies were either case reports or case series (97\%), describing 1 to 11 cases. One of the studies was a case series combined with a retrospective cohort; however, for the purpose of our study, it was counted only as a case series. ${ }^{26}$ The remaining prospective or retrospective studies reported an $\mathrm{n}$ value ranging from 9 to 800. Retrospective studies were evaluated using the National Heart, Lung, and Blood Institute Study Quality Assessment Tools (Supplemental Appendix S2).

\section{Discussion}

In this narrative review, we describe 291 patients with RVOTO. In all 233 reports, we determined the cause for RVOTO and classified it by etiology and location. The most commonly reported pathology is neither congenital nor iatrogenic, corresponding to $60 \%$ of reported cases. The most common type of RVOTO documented was extrinsic and mechanical, which means it is secondary to a pathology found outside of the RVOT that is physically obstructing the outflow of blood from the RV to the PA. In congenital cases, the most common pathology was hypertrophic cardiomyopathy, in which a thickened myocardium mechanically obstructed the RVOT. Acknowledging that RVOTO is a key pathophysiological finding in several more common congenital cardiopathies characterized by hypoplasia of RV outflow structures (such as a tetralogy of Fallot or certain cases of double outlet right ventricle), it seems likely that this result is in part affected by reporting bias. Indeed, it is more common for physicians to report a rare and unusual case compared to a case presenting as expected. Even though the numbers and proportions should be interpreted with caution, our findings nonetheless reveal that RVOTO can be present in a large variety of congenital heart diseases in an adult population, beyond the most obvious pathologies. With one exception, in which RVOTO happened during induction of anesthesia, ${ }^{223}$ most reported cases of iatrogenic RVOTO occurred after either cardiac or thoracic surgery.

The total number of cases of RVOTO during a specific period determines the prevalence. The total number of patients in 4 reported studies is 1122 . Given that 3 of these 4 studies focused on specific populations, the prevalence of RVOTO cannot be generalized from these. The remaining study gives a more representative overview of RVOTO in an adult surgery population: Denault et al. reported a cohort of 670 adult patients who underwent intraoperative TEE, and a prospective cohort of 130 patients. ${ }^{122}$ In this study, the majority of TEEs were performed in patients in the operating room in a centre specialized for adult cardiac surgery.

There is no clear-cut consensus regarding the definition of RVOTO. The diagnosis can be made with imaging modalities 

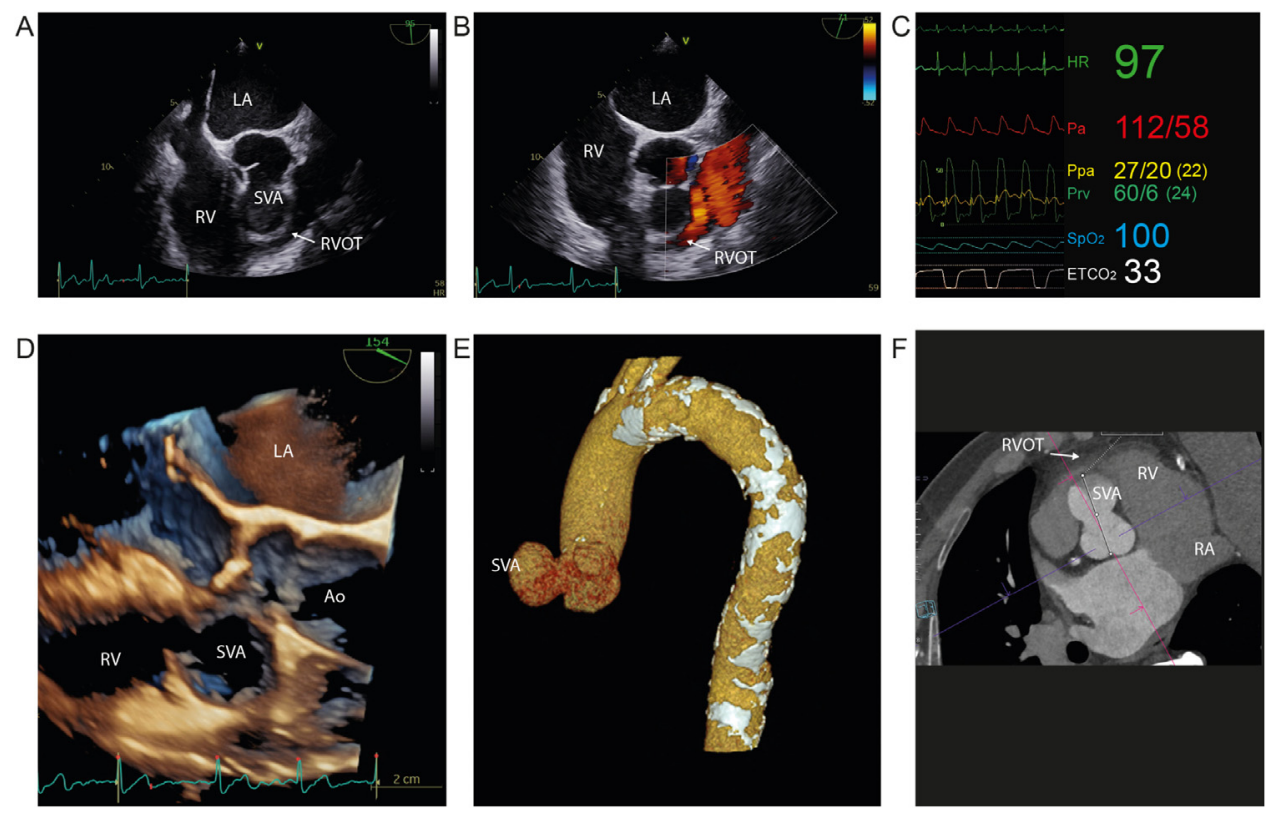

Figure 2. Aneurysm of Valsalva causing right ventricular outflow tract (RVOT) obstruction. (A) Mid-esophageal inflow/outflow view with sinus of Valsalva aneurysm (SVA) at the level of the right coronary cusp aneurysm causing an obstruction in the RVOT. (B) Note the color Doppler acceleration after the obstruction. (C) An intraoperative systolic pressure gradient of $33 \mathrm{~mm}$ Hg was observed between the pulmonary artery pressure (Ppa) and the right ventricular pressure (Prv). (D) Intraoperative 3-dimensional view of the RVOT. (E) Aortic reconstruction and (F) computed tomography showing the SVA obstructing the RVOT. (Video 1 ... (x, view video online.) Ao, aorta; $\mathrm{ETCO}_{2}$, end-tidal carbon dioxide; HR, heart rate; LA, left atrium; Pa, arterial pressure; RA, right atrium; $\mathrm{RV}$, right ventricle; $\mathrm{SpO}_{2}$, oxygen saturation using pulse oximetry.
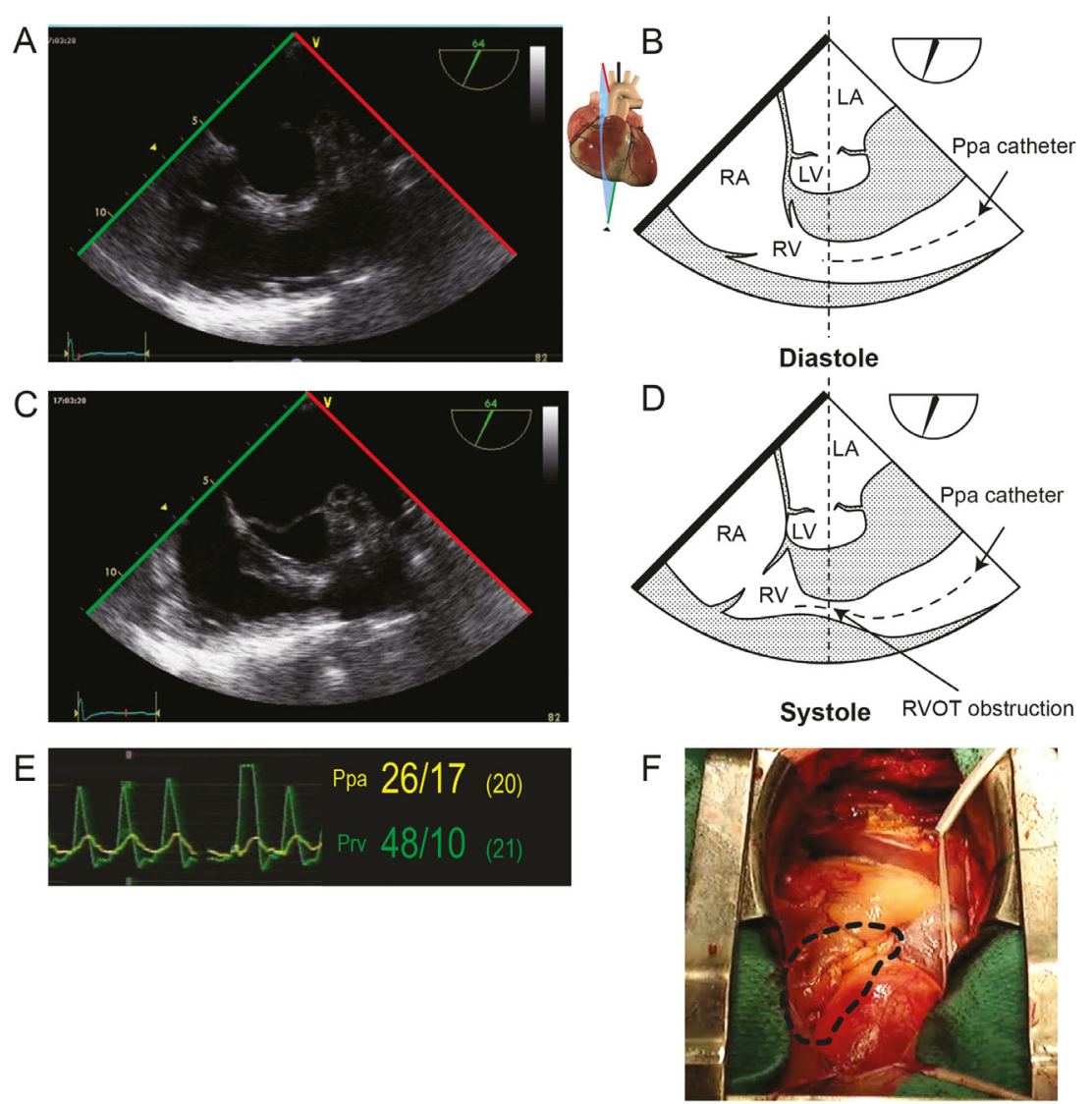

Figure 3. Intrinsic dynamic iatrogenic obstruction of the right ventricular outflow tract (RVOT). Mid-esophageal inflow/outflow views during (A, B) diastole and (C, D) systole. Notice the significant decrease in the size of the RVOT tract during systole. (E) Systolic pressure gradient of $22 \mathrm{~mm} \mathrm{Hg}$ between the pulmonary artery pressure (Ppa) and the right ventricular pressure (Prv) across the RVOT. (F) Intraoperative aspect of the RVOT obstruction (dotted line). (See Videos 2 and 3 . (n. view videos online.) LA, left atrium; LV, left ventricle; RA, right atrium; RV, right ventricle. Reproduced with permission of Taylor and Francis Group, LLC, a division of Informa plc. from Denault et al. ${ }^{251}$ @ 2018 Taylor and Francis Group. 

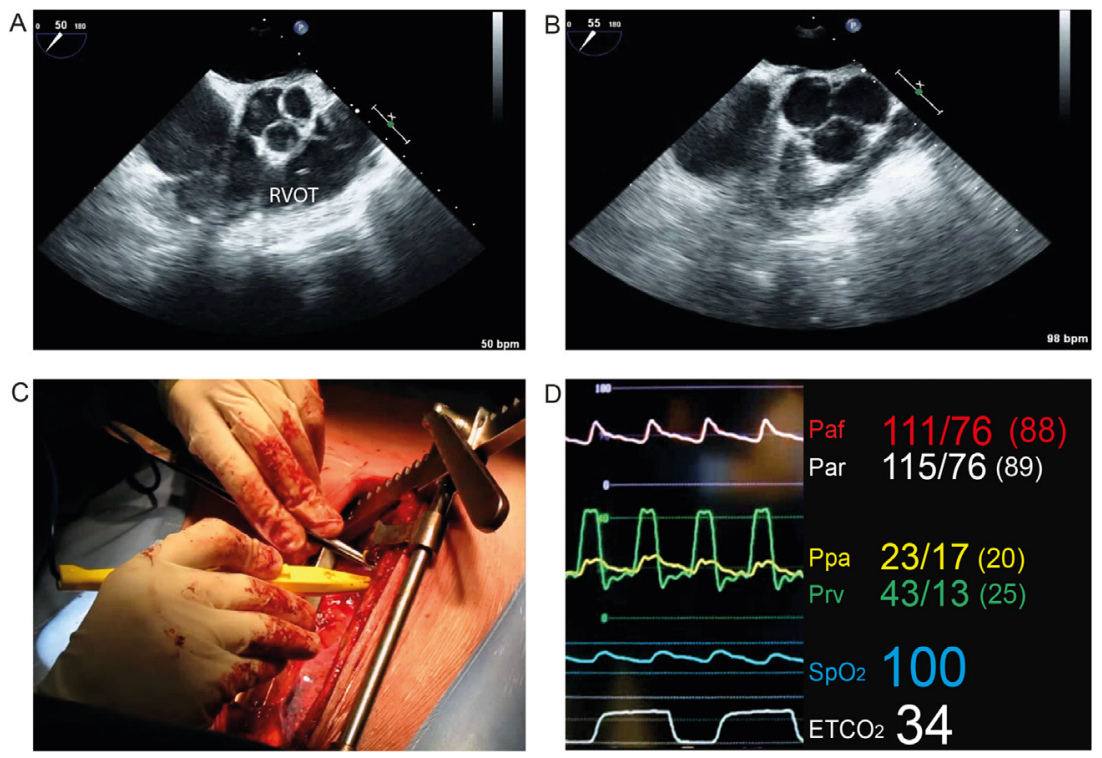

Figure 4. Transient right ventricular outflow tract (RVOT) obstruction during right mammary dissection. Mid-esophageal inflow/outflow view (A) before and (B) after the beginning of the right mammary dissection. (C) The surgical retractor was compressing the RVOT, causing hemodynamic instability and a systolic pressure gradient of $20 \mathrm{~mm} \mathrm{Hg}$ (D) between the pulmonary artery pressure (Ppa) and the right ventricular pressure (Prv). $\mathrm{ETCO}_{2}$, end-tidal carbon dioxide; Paf, femoral arterial pressure; Par, radial arterial pressure; $\mathrm{SpO}_{2}$, oxygen saturation using pulse oximetry. (Videos 4 and 5 证...

such as CT, magnetic resonance imaging, TTE, or TEE. ${ }^{239}$ Hemodynamic measurements of pressure gradients across the RVOT using catheterization, Doppler echocardiography, or a PA catheter with an RV port can be used (Fig. 2; Video 1 P...n, view video online). Dynamic and mechanical RVOTO can be seen in real time intraoperatively (Figs. 3 and 4; Videos 2-5 mented a multimodal approach to confirm and identify the extent of the RVOTO. In the studies we examined, the diagnosis was made during preoperative evaluations, intraoperatively during surgery (Figs. 2-4), postoperatively, in the intensive care unit (Figs. 5-7; Videos 6-9 官....7, view videos online) following discharge from surgery, or on autopsy. Hemodynamic measurement of pressure gradients represents the most precise method for RVOTO identification and would allow for identification of the prevalence of this phenomenon when performed in a nonspecific population.

\section{Importance and treatment of RVOTO}

It is important to recognize RVOTO and correctly diagnose the underlying pathology in order to implement appropriate management. For example, mechanical RVOTO due to an RV-PA conduit or homograft failure requires specific operative management (either open or percutaneous), as compared to RVOTO due to a dynamic iatrogenic cause. As for a dynamic obstruction, it is typically reported after lung transplantation (Fig. 6). In patients receiving inotropes, the term "suicide RV" has been used to describe the acute onset of dynamic RVOTO. ${ }^{10,67,231}$ Kirshbom et al. provided a very convincing hypothesis explaining this phenomenon. ${ }^{70}$ Pulmonary allograft candidates often suffer from chronic pulmonary hypertension, leading to structural changes in the heart. As a result, the interventricular septum deviates to the left while the right ventricle dilates and hypertrophies. After lung transplantation, the RV afterload abruptly decreases, and its
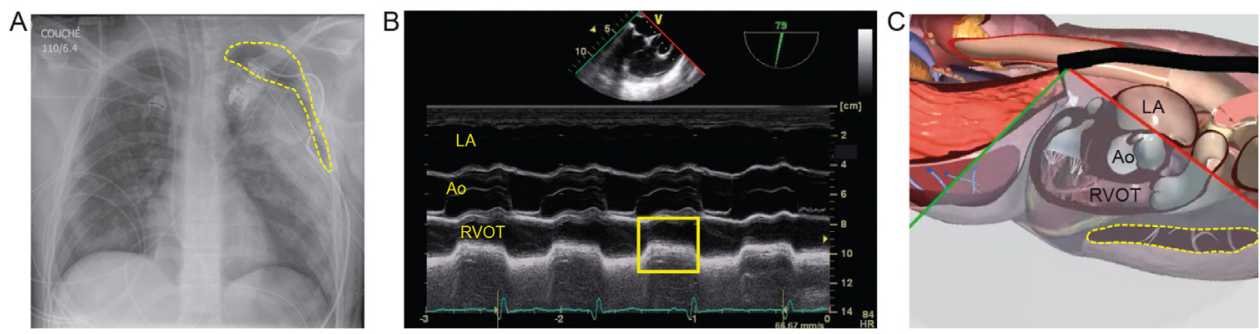

Figure 5. Extrinsic mechanical iatrogenic right ventricular outflow tract (RVOT) obstruction caused by a left-sided tension pneumothorax. (A) A left pneumothorax is shown on the chest radiograph. (B) Mid-esophageal view of the RVOT on transesophageal echocardiography. A constant diastolic obstruction of the RVOT is present on M-mode. (C) The obstruction is caused by compression on the RVOT by the antero-medial portion of the left pneumothorax as shown on the CAE-Vimedix simulator (CAE Healthcare Inc., Montreal, Canada). (See Video 6 汪... view video online.) Ao, aorta; LA, left atrium. Reproduced with permission of Taylor and Francis Group, LLC, a division of Informa plc. from Denault et al. ${ }^{251}$ (c) 2018 Taylor and Francis Group. 
POSITIVE-PRESSURE EXPIRATION

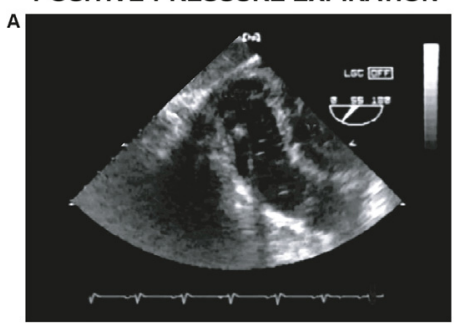

POSITIVE-PRESSURE INSPIRATION

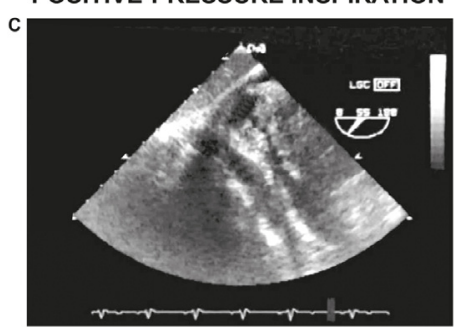

B
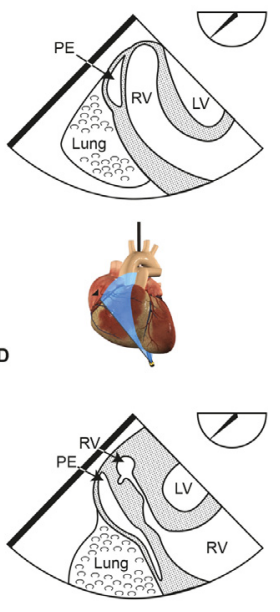

Figure 6. Right ventricular outflow tract (RVOT) obstruction after single lung transplantation. Deep transgastric RVOT views at $55^{\circ}$ during (A, B) positive-pressure expiration and (C, D) inspiration show extrinsic RVOT collapse from positive-pressure ventilation. (See Video 7 ...m, view video online.) LV, left ventricle; PE, pericardial effusion; RV, right ventricle. Reproduced with permission of Taylor and Francis Group, LLC, a division of Informa plc. from Denault et al. ${ }^{251}$ (c) 2018 Taylor and Francis Group.

systolic function improves. The septal deviation toward the left resolves, the RV volume decreases, and the hypertrophic right ventricle can predispose to a dynamic RVOTO. This condition can be exacerbated if the patient is exposed to inotropic agents that increase the RV contractility and decrease RV end-systolic volume, further worsening RVOTO. The resulting tachycardia, reduced diastolic filling time, and RV volume could aggravate the RVOTO ${ }^{70}$ In such cases, betablockers should be a preferred treatment when RVOTO is noticed, because these medications decrease heart contractility, increase RV volume, and increase diastolic filling time. ${ }^{247,248}$ As previously discussed, RVOTO, particularly when dynamic, is likely underdiagnosed in the postoperative cardiac surgery population. This underdiagnosis is a result of the fact that dynamic obstructions are transient (up to 5 minutes), thus rendering their identification difficult without continuous monitoring using a PA catheter, and they are often undetected when using echocardiography alone. Careful positioning of the PA catheter is important because in small patients distal PA position can result in overestimation of an RVOTO (Fig. 8; Video 10 啹...n, view video online).

The treatment of RVOTO will depend on its etiology. In the case of postsurgical dynamic obstruction, inotrope withdrawal, volume expansion, and the use of beta-blockers or calcium-channel inhibitors should be considered. Mechanical cases will likely require surgical intervention. It is therefore paramount that clinicians be able to detect RVOTO early so
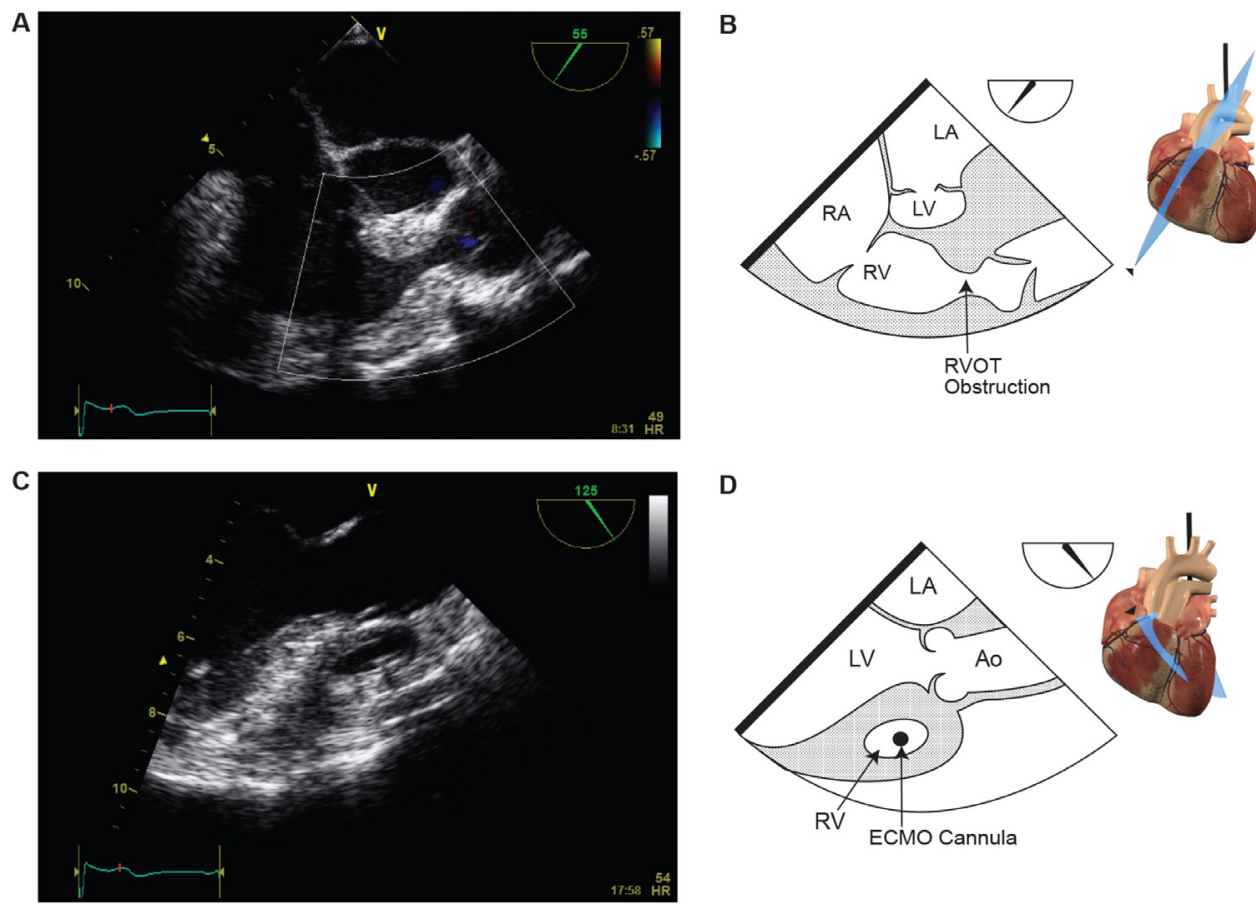

D

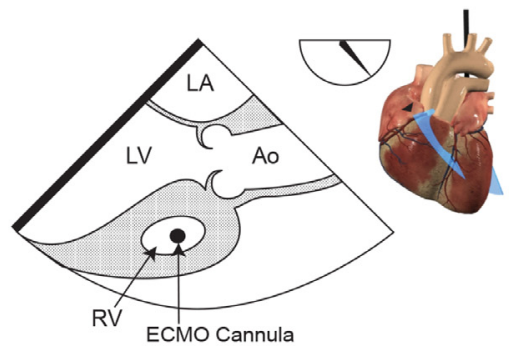

Figure 7. Right ventricular outflow tract (RVOT) obstruction after single lung transplantation. A patient after single lung transplantation requiring extracorporeal membrane oxygenation (ECMO). (A, B) The mid-esophageal right ventricular inflow/outflow view shows significant edema causing RVOT obstruction just below the pulmonic valve. (C, D) Mid-esophageal long-axis view also shows RVOT obstruction and the ECMO cannula in the RVOT. (See Videos 8 and 9 ...n (r. view videos online.) Ao, aorta; LA, left atrium; LV, left ventricle; RA, right atrium; RV, right ventricle. Courtesy of Dr Jens Lohser from the Vancouver General Hospital; reproduced from Denault et al. ${ }^{252}$ with permission of Taylor and Francis Group, LLC, a division of Informa plc. (C) 2011 Informa Healthcare. 

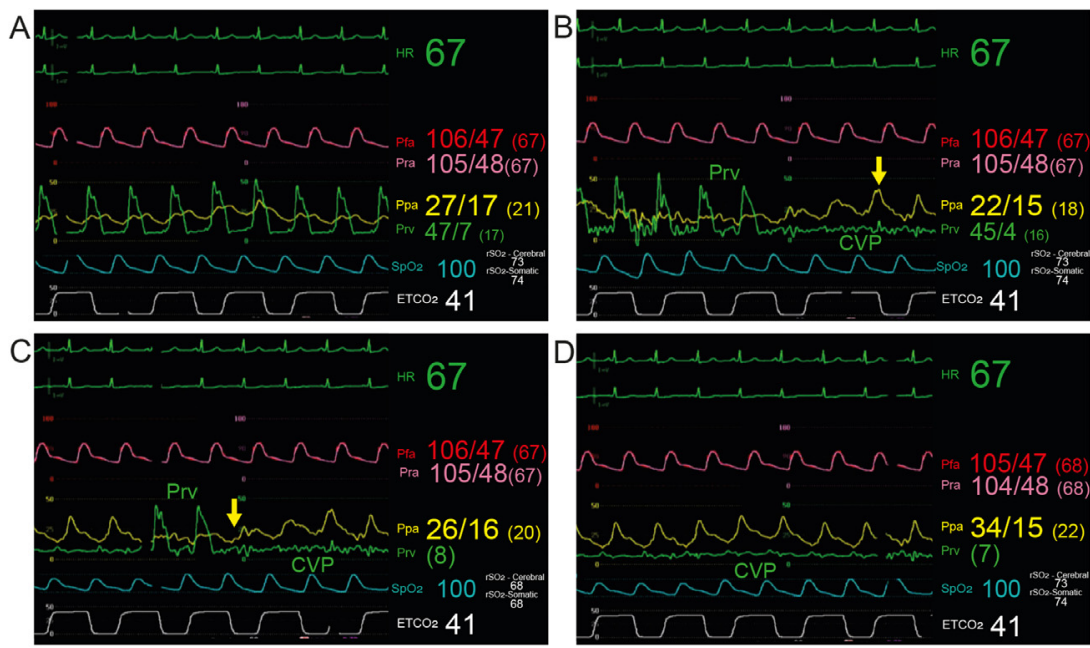

Figure 8. Pseudo right ventricular outflow tract obstruction. Hemodynamic waveforms in a 73-year-old man undergoing revascularization. (A) A $20 \mathrm{~mm} \mathrm{Hg}$ systolic gradient between the right ventricular pressure (Prv) and the pulmonary artery pressure (Ppa) is present. (B) Pulling back the pulmonary artery pressure reveals a higher Ppa (arrow). (C) The lower Ppa (arrow) was present with the Prv because the pulmonary artery catheter was damped from a distal position. (D) Normal Ppa and central venous pressure (CVP). The maximal systolic gradient between the Ppa and the Prv is $13 \mathrm{~mm} \mathrm{Hg}$ instead of $20 \mathrm{~mm} \mathrm{Hg}$. (See Video 10 ...m, view video online.) ETCO2, end-tidal carbon dioxide; HR, heart rate; Pfa, femoral arterial pressure; Pra, radial arterial pressure; rSO2, regional oxygen saturation; SpO2, oxygen saturation using pulse oximetry.

they can further investigate the cause and ultimately treat it according to the etiology. Hemodynamic instability during prone positioning can result from RVOTO as the RVOT is compressed between the spine and sternum. ${ }^{249,250}$ Returning the patient to a supine position should relieve the obstruction.

\section{Limitations}

There are several limitations to this systematic review. First, most retrieved studies were either case reports or case series with a very small number of patients and are regarded as the lowest-quality form of scientific evidence. Second, because there were so few retrospective studies on RVOTO, the number of articles retrieved on RVOTO in the non-selected adult cardiac and non-cardiac surgery populations was very low. For this reason, estimates of prevalence are limited by the heterogeneity of studies. Third, only one database (PubMed) was

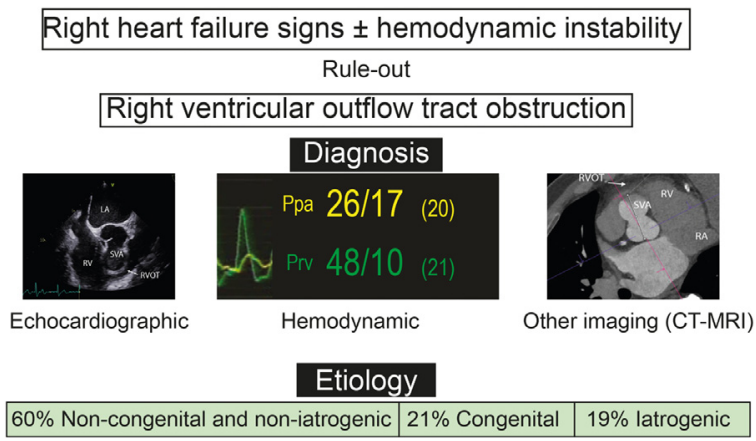

Figure 9. Approach to right ventricular outflow tract obstruction. CT, computed tomography; LA, left atrium; MRI, magnetic resonance imaging; Ppa, pulmonary artery pressure; Prv, right ventricular pressure; RA, right atrium; RV, right ventricle; RVOT, right ventricular outflow tract; SVA, sinus of Valsalva aneurysm. searched, and almost half of the articles included in the study were obtained from bibliographies or by using reverse citation, calling into question the appropriateness of the search strategy. However, we still consider it unlikely that high-quality studies on the prevalence and etiology of RVOTO were missed. Finally, the arbitrary definition and stratification of RVOTO as moderate (RV-PA systolic pressure gradient of $6-25 \mathrm{~mm} \mathrm{Hg}$ ) or severe $(>25 \mathrm{~mm} \mathrm{Hg}$ ) will require further validation and outcome studies as there is no clear consensus regarding its definition. A currently registered prospective study (NCT04092855) will determine the exact prevalence of RVOTO in cardiac surgical patients.

\section{Conclusion}

Cases of RVOTO have been reported mostly in the cardiac surgical population, yet this complication can occur in any patient with predisposing factors (Fig. 9). This review included 291 patients from 233 studies on reported cases of RVOTO. The most common etiology was non-congenital and non-iatrogenic. Most cases of RVOTO were found to be due to causes that were extrinsic and mechanical in nature. A meta-analysis on 5 cohorts suggests that the prevalence of this phenomenon in the adult cardiac surgery population is $4.0 \%$; however, these studies present moderate heterogeneity. Further studies documenting the prevalence of RVOTO using standardized criteria and its association with other clinical factors will help us better understand this uncommon and possibly underreported diagnosis.

\section{Funding Sources}

This study was supported by the Montreal Heart Institute Foundation and the Richard I. Kaufman Endowment Fund in Anesthesia and Critical Care. The funding sources had no 
involvement in this report. The authors have no other funding sources to declare.

\section{Disclosures}

André Denault is on the speaker's bureau for CAE Healthcare (2012), Masimo (2017), and KOL (2020), and received an equipment grant from Edwards (2019). William BeaubienSouligny is supported by the FRQS/MSSS Phase 3 Program. The other authors have no conflicts of interest to disclose.

\section{References}

1. Davila-Roman VG, Waggoner AD, Hopkins WE, Barzilai B. Right ventricular dysfunction in low output syndrome after cardiac operations: assessment by transesophageal echocardiography. Ann Thorac Surg 1995;60:1081-6.

2. Denault AY, Couture P, Beaulieu Y, et al. Right ventricular depression after cardiopulmonary bypass for valvular surgery. J Cardiothorac Vasc Anesth 2015;29:836-44.

3. Estrada VH, Franco DL, Moreno AA, Gambasica JA, Nunez CC. Postoperative right ventricular failure in cardiac surgery. Cardiol Res 2016;7:185-95.

4. Bootsma IT, de Lange F, Koopmans M, et al. Right ventricular function after cardiac surgery is a strong independent predictor for longterm mortality. J Cardiothorac Vasc Anesth 2017;31:1656-62.

5. Verbrugge FH, Dupont M, Steels P, et al. Abdominal contributions to cardiorenal dysfunction in congestive heart failure. J Am Coll Cardiol 2013;62:485-95.

6. Sundaram V, Fang JC. Gastrointestinal and liver issues in heart failure. Circulation 2016;133:1696-703.

7. Therrien J, Dore A, Gersony W, et al. CCS Consensus Conference 2001 update: recommendations for the management of adults with congenital heart disease. Part I. Can J Cardiol 2001;17:940-59.

8. Raymond M, Gronlykke L, Couture EJ, et al. Perioperative right ventricular pressure monitoring in cardiac surgery. J Cardiothorac Vasc Anesth 2019;33:1090-104.

9. Bashore TM. Adult congenital heart disease: right ventricular outflow tract lesions. Circulation 2007;115:1933-47.

10. Singhal A, Kumar S, Kapoor A. Sudden iatrogenic suicidal right ventricle. Indian Heart J 2015;67:406-8.

11. Dall'Agata A, Cromme-Dijkhuis AH, Meijboom FJ, et al. Use of threedimensional echocardiography for analysis of outflow obstruction in congenital heart disease. Am J Cardiol 1999;83:921-5.

12. Putterman C, Gilon D, Uretzki G, Bar-Ziv J, Polliack A. Right ventricular outflow tract obstruction due to extrinsic compression by nonHodgkin's lymphoma: importance of echocardiographic diagnosis and follow up. Leuk Lymphoma 1992;7:211-5.

13. Kaushal SK, Radhakrishanan S, Dagar KS, et al. Significant intraoperative right ventricular outflow gradients after repair for tetralogy of Fallot: to revise or not to revise? Ann Thorac Surg 1999;68:1705-12. discussion 1712-3.

14. Balduzzi S, Rucker G, Schwarzer G. How to perform a meta-analysis with R: a practical tutorial. Evid Based Ment Health 2019;22:153-60.

15. Doohen DJ, Greer JW, Diorio N, Timmes JJ. Emergency excision of a myxoma of the right ventricle which was obstructing the right ventricular outflow tract. J Thorac Cardiovasc Surg 1964;47:342-8.
16. Goldstein S, Mahoney EB. Right ventricular fibrosarcoma causing pulmonic stenosis. Am J Cardiol 1966;17:570-8.

17. Kiser JC, Ongley PA, Kirklin JW, Clarkson PM, McGoon DC. Surgical treatment of dextrocardia with inversion of ventricles and double-outlet right ventricle. J Thorac Cardiovasc Surg 1968;55:6-15.

18. Rawls WJ, Shuford WH, Logan WD, Hurst JW, Schlant RC. Right ventricular outflow tract obstruction produced by a myocardial abscess in a patient with tuberculosis. Am J Cardiol 1968;21:738-45.

19. McLoughlin MJ. Obstruction of the right ventricular outflow tract due to metastasis. Br J Radiol 1970;43:573-6.

20. Hubbard TF, Neil RN. Myxoma of the right ventricle. Report of a case with unusual findings. Am Heart J 1971;81:548-53.

21. Kerber RE, Ridges JD, Kriss JP, et al. Unruptured aneurysm of the sinus of valsalva producing right ventricular outflow obstruction. Am J Med 1972;53:775-83.

22. Merin G, Borman JB, Aviad I, Maddock CR, Stern S. Double aortic arch associated with coarctation, ventricular septal defect and right ventricular outflow tract obstruction. Successful surgical repair. Am J Cardiol 1972;29:564-7.

23. Gordon R, Kimbiris D, Segal BL. Obstruction of the right ventricular outflow tract due to metastatic hypernephroma. Vasc Surg $1973 ; 7: 213-9$.

24. Zager J, Smith JO, Goldstein S, Franch RH. Tricuspid and pulmonary valve obstruction relieved by removal of a myxoma of the right ventricle. Am J Cardiol 1973;32:101-4.

25. Kleinfeld M, Rozanski JJ, Brumlik JV. Situs inversus, subaortic and subpulmonic stenosis, ventricular septal defect, and single coronary artery. Chest 1976;70:391-3.

26. Shmookler BM, Marsh HB, Roberts WC. Primary sarcoma of the pulmonary trunk and/or right or left main pulmonary artery—a rare cause of obstruction to right ventricular outflow. Report on two patients and analysis of 35 previously described patients. Am J Med $1977 ; 63: 263-72$.

27. Griffith DN, Myers A. Obstruction of right ventricular outflow tract by solitary ovarian metastasis. Br Heart J 1978;40:700-2.

28. Betancourt B, Defendini EA, Johnson C, et al. Severe right ventricular outflow tract obstruction caused by an intracavitary cardiac neurilemoma: succesful surgical removal and postoperative diagnosis. Chest $1979 ; 75: 522-4$.

29. Birmingham CL, Peretz DI. Metastatic carcinoma presenting as obstruction to the right ventricular outflow tract. Report of a case and review of the literature. Am Heart J 1979;97:229-32.

30. Silvestre A, Benchimol A, Desser KB, Sheasby C. Septal aneurysm and right ventricular obstruction: a case report. Angiology 1979;30:56-61.

31. Hada Y, Wolfe C, Murray GF, Craige E. Right ventricular myxoma. Case report and review of phonocardiographic and auscultatory manifestations. Am Heart J 1980;100:871-7.

32. Steffens TG, Mayer HS, Das SK. Echocardiographic diagnosis of a right ventricular metastatic tumor. Arch Intern Med 1980;140:122-3.

33. Ceretto WJ, Miller ML, Shea PM, Gregory CW, Vieweg WV. Malignant mesenchymoma obstructing the right ventricular outflow tract. Am Heart J 1981;101:114-5.

34. Upward JW, Daly K, Jackson G. Pericardial abscess causing right ventricular outflow tract obstruction. Successful surgical correction. Br Heart J 1983;49:507-9. 
35. Ellis JH, Hobbs RE, Moodie DS, Yiannikas J, Gill CC. Recurrent sinus of Valsalva aneurysm with right ventricular outflow tract obstruction. Cleve Clin Q 1984;51:77-81.

36. Lo HM, Tseng YZ, Tseng CD, et al. Intracardiac goiter: a cause of right ventricular outflow obstruction and successful operative therapy. Am J Cardiol 1984;53:976-8.

37. Norell MS, Sarvasvaran R, Sutton GC. Solitary tumour metastasis: a rare cause of right ventricular outflow tract obstruction and sudden death. Eur Heart J 1984;5:684-8.

38. Przybojewski JZ. Primary cardiac hydatid disease. A case report. S Afr Med J 1984;65:438-42

39. Warnes CA, Maron BJ, Jones M, Roberts WC. Asymptomatic sinus of Valsalva aneurysm causing right ventricular outflow obstruction before and after rupture. Am J Cardiol 1984;54:1383-4.

40. Come PC, Come SE, Riley MF, Carl LV, Nakao S. Reversible right ventricular outflow tract compression by immunoblastic sarcoma. Am J Cardiol 1985;55:239-40.

41. Desai AG, Sharma S, Kumar A, Hansoti RC, Kalke BR. Echocardiographic diagnosis of unruptured aneurysm of right sinus of Valsalva: an unusual cause of right ventricular outflow obstruction. Am Heart J 1985;109:363-4.

42. Nishimura RA, Kazmier FJ, Smith HC, Danielson GK. Right ventricular outflow obstruction caused by constrictive pericardial disease. Am J Cardiol 1985;55:1447-8

43. Shemin RJ, Marsh JD, Schoen FJ. Benign intracardiac thyroid mass causing right ventricular outflow tract obstruction. Am J Cardiol $1985 ; 56: 828-9$.

44. Antonelli G, Chiddo A, Bortone A, Iliceto S, Rizzon P. Hydatid cyst of the interventricular septum causing obstruction of the right ventricular outflow tract: cross-sectional echocardiographic, angiographic and pathological findings. Eur Heart J 1986;7:1083-5.

45. Hara K, Ohno M, Takenaga M, et al. [Metastatic thyroid cancer to the right ventricle causing obstruction of the right ventricular outflow tract and associated with disseminated intravascular coagulopathy: a case report]. J Cardiogr 1986;16:765-73. [in Japanese].

46. Kiefaber RW, Tabakin BS, Coffin LH, Gibson TC. Unruptured sinus of Valsalva aneurysm with right ventricular outflow obstruction diagnosed by two-dimensional and Doppler echocardiography. J Am Coll Cardiol 1986;7:438-42.

47. Talley JD, Franch RH, Clements SD, Murphy DA, Sewell CW. Primary right ventricular leiomyosarcoma producing outflow tract obstruction. Am Heart J 1986;112:1335-8.

48. Velebit V, von Segesser L, Gabathuler J, Jornod J, Faidutti B. Right ventricular outflow obstruction after radiation therapy. J Thorac Cardiovasc Surg 1986;92:153-5

49. Emmot WW, Vacek JL, Agee K, Moran J, Dunn MI. Metastatic malignant melanoma presenting clinically as obstruction of the right ventricular inflow and outflow tracts. Characterization by magnetic resonance imaging. Chest 1987;92:362-4.

50. Grigg LE, Downey W, Tatoulis J, Hunt D. Benign congenital intracardiac thyroid and polycystic tumor causing right ventricular outflow tract obstruction and conduction disturbance. J Am Coll Cardiol 1987;9:225-7.

51. Stierle U, Sheikhzadeh A, Shakibi JG, Langbehn AF, Diederich KW. Right ventricular obstruction in various types of hypertrophic cardiomyopathy. Jpn Heart J 1987;28:115-25.
52. Bartels P, O'Callaghan WG, Peyton R, Sethi G, Maley T. Metastatic liposarcoma of the right ventricle with outflow tract obstruction: restrictive pathophysiology predicts poor surgical outcome. Am Heart J 1988;115:696-8.

53. Vallance PJ, Gray HH, Oldershaw PJ. Diagnostic features of localised pericardial constriction. Int J Cardiol 1988;20:416-9.

54. Israeli A, Rein AJ, Krivisky M, et al. Right ventricular outflow tract obstruction due to extracardiac tumors. A report of three cases diagnosed and followed up by echocardiographic studies. Arch Intern Med 1989;149:2105-6.

55. Fremes SE, Patterson GA, Williams WG, et al. Single lung transplantation and closure of patent ductus arteriosus for Eisenmenger's syndrome. Toronto Lung Transplant Group. J Thorac Cardiovasc Surg $1990 ; 100: 1-5$

56. Haraphongse M, Ayudhya RK, Jugdutt B, Rossall RE. Isolated unruptured sinus of Valsalva aneurysm producing right ventricular outflow obstruction. Cathet Cardiovasc Diagn 1990;19:98-102.

57. Kamlow FJ, Padaria SF, Wainwright RJ. Metastatic cardiac malignant fibrous histiocytoma presenting as right ventricular outflow tract obstruction. Clin Cardiol 1991;14:173-5.

58. Reiss N, Theissen P, Feaux de Lacroix W. Right-ventricular hemangioma causing serious outflow-tract obstruction. Thorac Cardiov Surg 1991;39:234-6

59. Labib SB, Schick Jr. EC, Isner JM. Obstruction of right ventricular outflow tract caused by intracavitary metastatic disease: analysis of 14 cases. J Am Coll Cardiol 1992;19:1664-8.

60. Agrawal NB, Khandeparkar JM, Oswal D, et al. Surgical correction of aneurysms of sinus of Valsalva - a report of 22 cases. Indian Heart J $1993 ; 45: 479-82$.

61. Gorcsan 3rd J, Reddy SC, Armitage JM, Griffith BP. Acquired right ventricular outflow tract obstruction after lung transplantation: diagnosis by transesophageal echocardiography. J Am Soc Echocardiog $1993 ; 6: 324-6$

62. Carroll JC, Quinn CC, Weitzel J, Sant GR. Metastatic renal cell carcinoma to the right cardiac ventricle without contiguous vena caval involvement. J Urol 1994;151:133-4.

63. Ignaszewski AP, Collins-Nakai RL, Kasza LA, et al. Aneurysm of the membranous ventricular septum producing subpulmonic outflow tract obstruction. Can J Cardiol 1994;10:67-70.

64. Mukadam ME, Kulkarni HL, Kumar CJ, Tendolkar AG. Right-ventricular myxoma presenting as right-ventricular outflow-tract obstruction-case report and review of the literature. Thorac Cardiov Surg $1994 ; 42: 243-6$

65. Ritchie ME, Davila-Roman VG, Barzilai B. Dynamic right ventricular outflow obstruction after single-lung transplantation. Biplane transesophageal echocardiographic findings. Chest 1994;105:610-1.

66. Tardif JC, Taylor K, Pandian NG, Schwartz S, Rastegar H. Right ventricular outflow tract and pulmonary artery obstruction by postoperative mediastinal hematoma: delineation by multiplane transesophageal echocardiography. J Am Soc Echocardiog 1994;7:400-4.

67. Kroshus TJ, Kshettry VR, Hertz MI, Everett JE, Bolman 3rd RM. Suicide right ventricle after lung transplantation for Eisenmenger syndrome. Ann Thorac Surg 1995;59:995-7.

68. Calderon M, Galvan J, Negri V, Verdin R. Right ventricular bypass for palliation of cardiac sarcoma. Texas Heart Inst J 1996;23:178-9. 
69. Kasprzak JD, Religa W, Krzeminska-Pakula M, et al. Right ventricular outflow tract obstruction by cardiac metastasis as the first manifestation of follicular thyroid carcinoma. J Am Soc Echocar$\operatorname{diog}$ 1996;9:733-5.

70. Kirshbom PM, Tapson VF, Harrison JK, Davis RD, Gaynor JW. Delayed right heart failure following lung transplantation. Chest 1996;109:575-7.

71. Soejima Y, Niwa A, Tanaka M, et al. Large right ventricular myxoma in a 79-year-old male. Intern Med 1996;35:380-2.

72. Balkin PW, Imoto EM. Treatment of malignant obstruction of the right ventricular outflow tract and pulmonary artery with metallic stents. Am J Roentgenol 1997;169:439-40.

73. Henderson W, Huckell VF, English JC, Fradet G. Right outflow tract obstruction by a pedunculated neurofibroma: case report and literature review. Can J Cardiol 1997;13:387-90.

74. Ng AF, Olak J. Pericardial cyst causing right ventricular outflow tract obstruction. Ann Thorac Surg 1997;63:1147-8.

75. Sebastian C, Knott-Craig CJ, Chandrasekaran K, et al. Giant coronary artery pseudoaneurysm causing pulmonary artery obstruction: a rare complication of coronary bypass surgery-a case report. Angiology 1997;48:1073-8.

76. Yilmaz AT, Demirkilic U, Ozal E, Tatar H, Ozturk OY. Aneurysms of the sinus of Valsalva. J Cardiovasc Surg (Torino) 1997;38:119-24.

77. Esaki M, Kagawa K, Noda T, et al. Primary cardiac leiomyosarcoma growing rapidly and causing right ventricular outflow obstruction. Intern Med 1998;37:370-5.

78. Sugi K, Yoshimura K, Fujita N, et al. Obstruction of the right ventricle outflow tract during right cardiac prolapse. Jpn J Thorac Cardiovasc Surg 1998;46:131-3.

79. Wankmuller H, Seitz K, Seitz G. Cardiac metastasis of a malignant fibrous histiocytoma occupying the right ventricle and infiltrating the myocardium. Ultraschall Med 1998;19:139-41.

80. Halcox JP. Non-surgical CHOP cures right ventricular outflow obstruction. Heart 1999;81:445-6.

81. Marques KM, De Cock CC, Visser CA. Isolated unruptured aneurysm of the right sinus of Valsalva causing right ventricular outflow obstruction. Heart 1999;81:447-8.

82. Van Camp G, De Mey J, Daenen W, Budts W, Schoors D. Pulmonary stenosis caused by extrinsic compression of an aortic pseudoaneurysm of a composite aortic graft. J Am Soc Echocardiog 1999;12:997-1000.

83. Beaver TA, Robb JF, Teufel EJ, Malenka DJ, Palac RT. Right ventricular outflow tract obstruction in an older woman: facilitated diagnosis with transesophageal echocardiography-guided biopsy. J Am Soc Echocardiogr 2000;13:622-5.

84. Casanova JB, Daly RC, Edwards BS, Tazelaar HD, Thompson GB. Intracardiac ectopic thyroid. Ann Thorac Surg 2000;70:1694-6.

85. Gopal AS, Arora NS, Messineo FC. Right ventricular myxoma. N Engl J Med 2000;342:295.

86. Kann BR, Kim WJ, Cilley Jr. JH, Marra SW, DelRossi AJ. Hemangioma of the right ventricular outflow tract. Ann Thorac Surg 2000;70:975-7.

87. Kono T, Takemura T, Hagino I, Matsumura G. Complete resection of cardiac leiomyosarcoma extending into the pulmonary trunk and right pulmonary artery. Ann Thorac Surg 2000;70:1412-4.

88. McElhinney DB, Chatterjee KM, Reddy VM. Double-chambered right ventricle presenting in adulthood. Ann Thorac Surg 2000;70:124-7.
89. Murakawa T, Takamoto S, Ezure M, et al. Metastatic hepatocellular carcinoma obstructing the right ventricular outflow tract. Jpn J Thorac Cardiovasc Surg 2000;48:516-9.

90. Zakynthinos EG, Kontogianni DD, Mpalafouta ME, Vassilakopoulos T. Right ventricular outflow obstruction caused by non-small cell lung carcinoma. Int J Cardiol 2000;75:313-4.

91. Hayashi S, Tojyo K, Uchikawa S, et al. Biventricular hypertrophic cardiomyopathy with right ventricular outflow tract obstruction associated with Noonan syndrome in an adult. Jpn Circ J 2001;65:132-5.

92. Katoh H, Murakami R, Shimada T. Cine magnetic resonance imaging of isolated right ventricular outflow obstruction in hypertrophic cardiomyopathy. Clin Radiol 2001;56:516-9.

93. Krishnamoorthy KM, Desai NB. Myxoma producing right-sided inflow and outflow obstruction. Int J Cardiol 2001;79:325-6.

94. Willaert W, Claessens P, Shoja A, et al. Ventricular outflow tract obstruction secondary to leiomyosarcoma of the right ventricle. Jpn Heart J 2001;42:377-86.

95. Agarwal S, Choudhary S, Saxena A, Ray R, Airan B. Giant pulmonary artery aneurysm with right ventricular outflow tract obstruction. Indian Heart J 2002;54:77-9.

96. Doshi SN, Kim MC, Sharma SK, Fuster V. Images in cardiovascular medicine. Right and left ventricular outflow tract obstruction in hypertrophic cardiomyopathy. Circulation 2002;106:e3-4

97. Gersak B, Lakic N, Gorjup V, et al. Right ventricular metastatic choriocarcinoma obstructing inflow and outflow tract. Ann Thorac Surg 2002;73:1631-3.

98. Youn HJ, Jung SE, Chung WS, et al. Obstruction of right ventricular outflow tract by extended cardiac metastasis from esophageal cancer. J Am Soc Echocardiogr 2002;15:1541-4.

99. Denault A, Ferraro P, Couture P, et al. Transesophageal echocardiography monitoring in the intensive care department: the management of hemodynamic instability secondary to thoracic tamponade after single lung transplantation. J Am Soc Echocardiogr 2003;16:688-92.

100. Mohanakrishnan L, Vijayakumar K, Sukumaran P, et al. Unruptured sinus of Valsalva aneurysm with right ventricular outflow obstruction. Asian Cardiovasc Thorac Ann 2003;11:74-6.

101. Paraskevaidis IA, Triantafilou K, Karatzas D, Kremastinos DT. Right ventricular multiple myxomas obstructing right ventricular outflow tract. J Thorac Cardiovasc Surg 2003;126:913-4.

102. Shimizu M, Kawai H, Yokota Y, Yokoyama M. Echocardiographic assessment of right ventricular obstruction in hypertrophic cardiomyopathy. Circ J 2003;67:855-60.

103. Thankachen R, Gnanamuthu R, Doshi H, Shukla V, Korula RJ. Unruptured aneurysm of the sinus of Valsalva presenting with right ventricular outflow obstruction. Texas Heart Inst J 2003;30:152-4.

104. Yamada N, Minato N, Ikeda K, Shimokawa T, Hisamatsu Y. Surgical treatment of primary pulmonary artery tumor: two cases of malignant fibrous histiocytoma and leiomyosarcoma. Jpn J Thorac Cardiovasc Surg 2003;51:557-61.

105. Anbarasu M, Krishna Manohar SR, Titus T, Neelakandhan KS. Oneand-a-half ventricle repair for right ventricular endomyocardial fibrosis. Asian Cardiovasc Thorac Ann 2004;12:363-5.

106. Baweja G, Nanda NC, Nekkanti R, et al. Three-dimensional transesophageal echocardiographic delineation of ventricular septal aneurysm 
producing right ventricular outflow obstruction in an adult. Echocardiography 2004;21:95-7.

107. Gunes Y, Erbas C, Okcun B, Babalik E. A case of ventricular septal aneurysm producing right ventricular outflow obstruction in an adult patient. Anadolu Kardiyol Derg 2004;4:346-7.

108. Miyaji K, Matsubara H, Kajiya M, et al. Failure of disopyramide to improve right ventricular outflow tract obstruction after living-donor lobar lung transplantation. Circ J 2004;68:1084-7.

109. Rastan AJ, Walther T, Mohr FW, Kostelka M. Leiomyosarcoma-an unusual cause of right ventricular outflow tract obstruction. Thorac Cardiov Surg 2004;52:376-7

110. Sharda A, Yadava OP, Dubey S, Ghadiok R. Unruptured sinus of valsalva aneurysm presenting as acute coronary syndrome. Indian Heart J 2004;56:155-7.

111. Totaro M, Miraldi F, Ghiribelli C, Biscosi C. Cardiac angiosarcoma arising from pulmonary artery: endovascular treatment. Ann Thorac Surg 2004;78:1468-70

112. Brestas PS, Malagari KS, Kelekis DA. Rare right ventricular myxoma detected incidentally on a FAST examination. J Clin Ultrasound 2005;33:143-5

113. Iba Y, Watanabe S, Akimoto T, Abe K, Koyanagi H. Pedicled cardiac hemangioma with right ventricular outflow tract obstruction. Jpn J Thorac Cardiovasc Surg 2005;53:269-71.

114. Ichinose T, Nakazato Y, Miyano H, et al. Severe infundibular pulmonary stenosis and coronary artery stenosis with ventricular tachycardia 24 years after mediastinal irradiation. Intern Med 2005;44:963-6.

115. Ishikawa K, Takanashi S, Mihara W, Fukui T, Hosoda Y. Surgical treatment for primary cardiac leiomyosarcoma causing right ventricular outflow obstruction. Circ J 2005;69:121-3.

116. Karagounis A, Sarsam M. Myxoma of the free wall of the right ventricle: a case report. J Card Surg 2005;20:73-6.

117. Prabhakar A, Dalmia RS, Gaur N, Khurana P, Trehan N. Isolated thrombus-producing right ventricular outflow tract obstruction: an unusual presentation of primary antiphospholipid antibody syndrome. Indian Heart J 2005;57:744-6.

118. Atik FA, Navia JL, Krishnamurthi V, et al. Solitary massive right ventricular metastasis of renal cell carcinoma without inferior vena cava or right atrium involvement. J Card Surg 2006;21:304-6.

119. Bhavani SS, Slisatkorn W, Rehm SJ, Pettersson GB. Deep sternal wire infection resulting in severe pulmonary valve endocarditis. Ann Thorac Surg 2006;82:1111-3.

120. Chiu KM, Lin TY, Li SJ, Chan CY, Chu SH. Hybrid pulmonary artery conduit angioplasty for heterotopic heart transplantation. Transplant Proc 2006;38:1538-40

121. Daccarett M, Burke P, Saba S. Incidental finding of a large pulmonary valve fibroelastoma: a case report. Eur J Echocardiogr 2006;7:253-6.

122. Denault AY, Chaput M, Couture P, et al. Dynamic right ventricular outflow tract obstruction in cardiac surgery. J Thorac Cardiovasc Surg 2006;132:43-9.

123. Kholeif MA, Tahir ME, Kholeif YA, Watidy AE. An unusual aneurysm of the main pulmonary artery presenting as acute coronary syndrome. Cardiovasc Intervent Radiol 2006;29:911-4.

124. May M, Finkbeiner Y, Gunia S, et al. Metastasizing testicular germ-cell tumor with infiltration of the right heart: indication for primary metastasectomy. Heart Vessels 2006;21:63-5.
125. Rosenberger P, Cohn LH, Fox JA, Locke A, Shernan SK. Sinus of Valsalva aneurysm obstructing the right ventricular outflow tract. Anesth Analg 2006;102:1660-1.

126. Bouzas-Mosquera A, Flores-Rios X, Aldama G. Primary cardiac rhabdomyosarcoma causing obstruction to the right ventricular outflow. Eur J Echocardiogr 2007;8:406-7.

127. Gelfand EV, Bzymek D, Johnstone MT. Images in cardiovascular medicine. Sinus of Valsalva aneurysm with right ventricular outflow tract obstruction: evaluation with Doppler, real-time 3-dimensional and contrast echocardiography. Circulation 2007;115:e16-7.

128. Krecki R, Lipiec P, Piotrowska-Kownacka D, et al. Predominant, severe right ventricular outflow tract obstruction in hypertrophic cardiomyopathy. Circulation 2007;116:e551-3.

129. Murakami T, Komiya A, Mikata K, Kaneko S, Ikeda I. Cardiac metastasis of renal pelvic cancer. Int J Urol 2007;14:240-1.

130. Ozbek C, Emrecan B, Calli AO, Gurbuz A. Intimal sarcoma of the pulmonary artery with retrograde extension into the pulmonic valve and right ventricle. Texas Heart Inst J 2007;34:119-21.

131. Sayin OA, Ugurlucan M, Cinar T, et al. Right ventricular myxoma causing right ventricular outflow tract obstruction. J Card Surg 2007;22:227-9.

132. Aktoz M, Tatli E, Ege T, et al. Cardiac rhabdomyoma in an adult patient presenting with right ventricular outflow tract obstruction. Int J Cardiol 2008;130:e105-7.

133. Butz T, Horstkotte D, Langer C, et al. Significant obstruction of the right and left ventricular outflow tract in a patient with biventricular hypertrophic cardiomyopathy. Eur J Echocardiogr 2008;9:344-5.

134. Coskun ST, Coskun KO, Popov AF, et al. Reoperations in adults after correction of tetralogy of Fallot. ASAIO J 2008;54:556-7.

135. Goksel OS, Badem S, Kaya AB, Tireli E, Dayioglu E. Aneurysm of right ventricular outflow tract with pulmonic stenosis 28 years after atrial septal defect repair. Anadolu Kardiyol Derg 2008;8:E5-6.

136. Nishida K, Fukuyama O, Nakamura DS. Pulmonary valve endocarditis caused by right ventricular outflow obstruction in association with sinus of Valsalva aneurysm: a case report. J Cardiothorac Surg 2008;3:46.

137. Omura A, Tobe S, Yoshida K, Yamaguchi M. Surgical treatment for recurrent pulmonary artery sarcoma. Gen Thorac Cardiovasc Surg 2008;56:28-31.

138. Rigatelli G, Cardaioli P, Dell'Avvocata F, Giordan M, Roncon L. Transcatheter-covered stent implantation in an unusual post-surgical right ventricle outflow tract stenosis. Eur Heart J 2008;29:1078.

139. Yang Y, Zhou Y, Ma L, Ni Y. Unruptured aneurysm of the sinus of Valsalva presenting with thrombosis and right ventricular outflow obstruction. J Card Surg 2008;23:782-4.

140. Agarwal R, Kumar N, Dixit S, et al. Hydatid cyst in the right ventricular outflow tract: successful surgical outcome of a rare entity. Indian J Thorac Cardiovasc Surg 2009;25:40-2.

141. Bijulal S, Sivasankaran S, Sanjay G, Tharakan J. Membranous septal aneurysm: an unusual cause for right ventricular outflow tract obstruction in a malaligned ventricular septal defect with aortomitral discontinuity (double-outlet right ventricle) associated with visceral heterotaxy. Pediatr Cardiol 2009;30:200-2.

142. Chen F, Hanaoka N, Hasegawa S, et al. Right ventricular outflow tract obstruction after bilateral lung transplantation. Thorac Cardiovasc Surg 2009;57:48-50. 
143. Chue CD, Hudsmith LE, Thorne SA, Clift P. Infected thrombus compression of the right ventricular outflow tract in transposition of the great arteries. Eur J Echocardiogr 2009;10:168.

144. Farand P, Brochu MC, Gervais A, Mueller X. Familial unruptured sinus of Valsalva aneurysm obstructing the right ventricular outflow tract. Can J Cardiol 2009;25:227-8.

145. Lee SH, Kim WH, Choi JB, et al. Huge primary pleomorphic leiomyosarcoma in the right ventricle with impending obstruction of both inflow and outflow tracts. Circ J 2009;73:779-82.

146. Martin M, Luyando LH, Moris C. Pulmonary infundibular stenosis and ventricular septum defect: usefulness of cardiac CT. Acta Cardiol 2009;64:269-70.

147. Ozer N, Deveci OS, Kaya EB, Demircin M. Mediastinal lymphoma causing extrinsic pulmonary stenosis. Turk Kardiyol Dern Ars 2009;37:421-4.

148. Avci A, Akcakoyun M, Alizada E, et al. Severe right ventricular outflow obstruction by right sinus of Valsalva aneurysm. Echocardiography 2010;27:341-3.

149. Ivanovic B, Tadic M, Matic D, Simic D. Right ventricular myxoma obstructing the outflow tract. Am Heart Hosp J 2010;8:E118-21.

150. Khouzam RN, Dearani JA, Julsrud PR. Ebstein's malformation presenting with tricuspid stenosis: 1-year follow-up after surgical repair. Cardiol Young 2010;20:80-5.

151. Lee C, Lee CH, Kwak JG, Park CS. Isolated accessory tricuspid valve causing right ventricular outflow tract obstruction. J Card Surg 2010;25:410-1.

152. Recupero A, Di Bella G, Patane S, et al. Right ventricular outflow tract obstruction in hypertrophic cardiomyopathy. Int J Cardiol 2010;144:e56-7.

153. Rosu C, Basile F, Prieto I, Noiseux N. Unusual presentation of an isolated unruptured aneurysm of the right sinus of Valsalva causing compression of the right ventricular outflow tract. Eur J Cardiothorac Surg 2010;38:504.

154. Takigawa M, Nakatani S, Hashimura K, et al. An elderly case of right ventricular outflow obstruction precisely diagnosed and successfully treated with surgical repair. Intern Med 2010;49:563-7.

155. Vida VL, Speggiorin S, Maschietto N, et al. Surgical re-utilization of a pulmonary valve graft after failed percutaneous treatment. J Heart Valve Dis 2010;19:260-2.

156. Chaudhry I, Bojal S, Poovathumkadavil A, Amr SS. Role of surgery after chemotherapy in B-cell lymphoma of thymus causing airway compression and right ventricle outflow tract obstruction. Ann Thorac Surg 2011;92:1120-2.

157. Chen SY, Chan KL, Beauchesne LM. Right ventricular outflow tract obstruction secondary to a membranous ventricular septal aneurysm. Eur J Echocardiogr 2011;12:886.

158. Darwazah AK, Eida M, Bader V, Khalil M. Surgical management of double-chambered right ventricle in adults. Texas Heart Inst J 2011;38:301-4.

159. Gajjar TP, Shah GB, Desai NB. Giant ventricular myxoma obstructing right ventricular outflow tract. Rev Bras Cir Cardiovasc 2011;26:663-6.

160. Garg N, Moorthy N, Agrawal SK, Pandey S, Kumari N. Delayed cardiac metastasis from phyllodes breast tumor presenting as cardiogenic shock. Texas Heart Inst J 2011;38:441-4.

161. Shah DK, Joyce LD, Grogan M, et al. Recurrent pulmonary intimal sarcoma involving the right ventricular outflow tract. Ann Thorac Surg 2011;91:e41-2.

162. Tsang FH, Cheng LC. Giant myxoma causing right ventricular outflow tract obstruction. Hong Kong Med J 2011;17:242-4.
163. Gil-Jaurena JM, Cano J, Cuenca V. Transaortic Fallot repair in a grown-up patient: advantages in a situs inversus setting. Cardiol Young 2012;22:603-5.

164. Guo HW, Xiong H, Xu JP, Wang XQ, Hu SS. Surgical correction for sinus of valsalva aneurysm with right ventricular outflow tract stenosis. J Card Surg 2012;27:99-102.

165. Matsushita T, Masuda S, Inoue T, Usui K, Yamagishi M. Deformities of pulmonary and aortic annulus 42 years after repair of tetralogy of Fallot. Ann Thorac Cardiovasc Surg 2012;18:48-50.

166. Obert L, Munyon R, Choe A, Rubenstein J, Azizkhan R. Rare late complication of the Nuss procedure: a case report. J Pediatr Surg 2012;47:593-7.

167. Pemberton J, Raudkivi P. Right ventricular myxoma causing pulmonary outflow tract obstruction. Interact Cardiovasc Thorac Surg 2012;14:362-3.

168. Rao N, Gajjar T, Desai N. Accessory mitral valve tissue: an unusual cause of congenital mitral stenosis. Interact Cardiovasc Thorac Surg 2012;14:110-2.

169. Sogawa M, Fukuda T, Tayama M, Moro H, Ishihara N. Reconstruction of the right ventricular outflow tract after surgical removal of a cardiac hemangioma. Gen Thorac Cardiovasc Surg 2012;60:661-3.

170. Tamenishi A, Matsumura Y, Okamoto H. Malignant fibrous histiocytoma originating from right ventricular outflow tract. Asian Cardiovasc Thorac Ann 2012;20:702-4.

171. Tsubota H, Nakamura T. Surgical correction of tetralogy of Fallot in a 61-year-old patient. Gen Thorac Cardiovasc Surg 2012;60:161-3.

172. Yagoub H, Srinivas BP, McCarthy J, Kiernan TJ. Gigantic unruptured sinus of Valsalva aneurysm presenting as an incidental murmur. BMJ Case Rep 2012;2012:bcr2012006824.

173. Altunbas G, Gokaslan G, Ercan S, Davutoglu V, Deniz H. Contribution of giant aneurysm of a membranous ventricular septal defect to right ventricular outflow tract obstruction. Thorac Cardiovasc Surg 2013;61:320-2.

174. Antonetti I, Lorch D, Coe B, et al. Unrepaired tetralogy of Fallot with major aortopulmonary collateral arteries in an adult patient. Congenit Heart Dis 2013;8:E24-30.

175. Bhat DP, Forbes TJ, Aggarwal S. A case of life-threatening Staphylococcus aureus endocarditis involving percutaneous transcatheter prosthetic pulmonary valve. Congenit Heart Dis 2013;8:E161-4.

176. Brown MR, Dettrick A, Javorsky G, McKenzie SC, Platts DG. Indolent cardiac angioma mimicking hypertrophic obstructive cardiomyopathy and causing right ventricular outflow tract obstruction. Eur Heart J Cardiovasc Imaging 2013;14:718.

177. Dryzek P, Goreczny S, Moszura T, et al. Right ventricular outflow tract giant pseudoaneurysm: percutaneous approach and complications. Kardiol Pol 2013;71:1076-8.

178. Fontana A, Corsi D, Vigano E, Trocino G, Achilli F. Added value of real time three-dimensional echocardiography in the diagnosis of an apical right ventricular metastasis from malignant melanoma. Echocardiography 2013;30:E16-20.

179. Gavali SA, Phadke MS, Kerkar PG, et al. Unruptured aneurysm of the sinus of Valsalva presenting with right ventricular outflow tract obstruction, complete heart block, and protrusion into left ventricular outflow tract: a rare combination. J Am Coll Cardiol 2013;61:e169.

180. Minagawa T, Watanabe S, Kanda K, Miura M, Tabayashi K. Surgical treatment for an asymptomatic and unruptured sinus of Valsalva aneurysm: report of a case. Surg Today 2013;43:1199-201. 
181. Mohsen A, Rahman F, Ikram S. Anomalous muscle bundles causing double-chambered right ventricle in adults. J Invasive Cardiol 2013;25:E212-3.

182. Obrenovic-Kircanski B, Mikic A, Velinovic M, et al. Right ventricular myxoma-a case report. Vojnosanit Pregl 2013;70:609-11.

183. Sah S, Berdjis F, Valdez S, Gates R. Pseudoaneurysm of surgically reconstructed right ventricular outflow tract. World J Pediatr Congenit Heart Surg 2013;4:116-9.

184. Yousif M, Elhassan NB, Ali SK, Ahmed Y. Isolated subpulmonic fibrous ring, mirror-image dextrocardia and situs solitus in a young lady unreported and a near miss. Interact Cardiovasc Thorac Surg 2013;17:1043-4.

185. Zanotti G, Hartwig MG, Davis RD. A simplified technique for pulmonary artery aneurysm repair in a lung transplant recipient with right ventricular outflow tract obstruction. J Thorac Cardiovasc Surg 2013;145:295-6.

186. Bang SH, Park JB, Chee HK, et al. Cardiac parasitic infection in trichinellosis associated with right ventricle outflow tract obstruction. Korean J Thorac Cardiovasc Surg 2014;47:145-8.

187. Bruckner BA, Rodriguez LE, Bunge R, et al. Large cardiac tumor managed with resection and two ventricular assist devices. Ann Thorac Surg 2014;97:321-4

188. Chen C, Gu J, Meng W, et al. Intraoperative evaluation of right ventricular outflow tract myxoma by real time three-dimensional transesophageal echocardiography. Echocardiography 2014;31:E174-6.

189. Cheng A, Thomas J, Vermilion RP, Alfieris GM, Hicks GL. Right ventricular outflow tract obstruction after sinus of Valsalva aneurysm repair. J Card Surg 2014;29:317-9.

190. Kokotsakis J, Rouska EG, Harling L, et al. Right ventricular outflow tract obstruction caused by double-chambered right ventricle presenting in adulthood. Texas Heart Inst J 2014;41:425-8.

191. Le DD, Orrego CM, Maragiannis D, Chang SM. An unusual case of right-sided heart failure caused by giant sinus of Valsalva aneurysm obstructing right ventricular outflow tract. Eur Heart J 2014;35:2721.

192. Madeo A, Pino PG, Pergolini A, Chialastri C, Buffa V. An unusual right ventricle outflow obstruction in adult. Anadolu Kardiyol Derg 2014;14:E9-10.

193. Malik R, Maron MS, Rastegar H, Pandian NG. Hypertrophic cardiomyopathy with right ventricular outflow tract and left ventricular intracavitary obstruction. Echocardiography 2014;31:682-5.

194. Patel N, Rousan TA, Peyton MD, Sivaram CA. Two different presentations of sinus of Valsalva aneurysm. Echocardiography 2014;31:E181-4.

195. Ramakrishnan S, Bhargava B, Seth S, Airan B. Alcohol ablation of right ventricular outflow tract obstruction. JACC Cardiovasc Interv 2014;7:443-5.

196. Song L, Wang L, Huang WC, et al. Primary leiomyoma: a rare space occupying lesion in the right ventricle. Ann Thorac Surg 2014;97:324-6.

197. Urban M, Besik J, Szarszoi O, Voska L, Netuka I. Right ventricular outflow tract obstruction caused by ectopic thyroid gland. Ann Thorac Surg 2014;98:345.

198. Yam N, Au TW. Right ventricular outflow tract obstruction by a pedunculated cardiac hemangioma: a rare case of syncope. J Card Surg 2014;29:351-2.

199. Buys DG, Greig C, Brown SC. First Melody $((\mathrm{R}))$ valve implantations in Africa. Cardiovasc J Afr 2015;26:196-9.

200. Chaudhry-Waterman N, Bergersen L, Buber J. Bacterial endocarditis manifesting as outflow tract obstruction in two patients implanted with percutaneous prosthetic pulmonary valves. Can J Cardiol 2015;31:1204. e1-3.
201. Das S, Ladha S, Airan B. Unruptured sinus of Valsalva aneurysm with right ventricular outflow tract obstruction and ventricular septal defect —a rare combination. Echocardiography 2015;32:1322-4.

202. Mahesh SK, Kumar S, Satheesh S, Jayaraman B. Real time threedimensional transesophageal echocardiography demonstration of membranous septal aneurysm causing severe right ventricular outflow tract obstruction. Echocardiography 2015;32:184-6.

203. Mohan JC, Mohan V. Bilateral outflow obstructions without ventricular septal defect in an adult: illustrated by real-time 3D echocardiography. Indian Heart J 2015;67:371-4.

204. Mori M, Siddharthan R, Kogon B. Extra-anatomic right ventricle to pulmonary artery conduit: the apical-aortic equivalent for complex right ventricular outflow tract reconstruction. Ann Thorac Surg 2015;99:1058-60.

205. Moustafa S, Patton DJ, Alvarez N, et al. Double chambered right ventricle with ventricular septal defect in adults: case series and review of the literature. J Cardiovasc Ultrasound 2015;23:48-51.

206. Omar HR, Mangar D, Fattouch T, Gibbs JD, Camporesi EM. Extracavitary cardiac carcinoid presenting with right ventricular outflow tract obstruction. Eur Heart J Cardiovasc Imaging 2015;16:345.

207. Osada H, Kyogoku M, Fujino T, Nakajima H. Partial aortic root replacement for aneurysm of the right sinus of Valsalva. Asian Cardiovasc Thorac Ann 2015;23:570-2.

208. Rier JD, Schoepf UJ, Renker M, Baumann S, Powers ER. Aortocoronary saphenous vein graft aneurysm causing high-gradient right ventricular outflow tract obstruction. Eur Heart J Cardiovasc Imaging 2015;16:117.

209. Sridhar GS, Sadiq MA, Ahmad WA, et al. Unruptured sinus of Valsalva aneurysm with right ventricular outflow tract obstruction and supracristal ventricular septal defect: a rare case. Texas Heart Inst J 2015;42:462-4

210. Torres A, Sanders SP, Vincent JA, et al. Iatrogenic aortopulmonary communications after transcatheter interventions on the right ventricular outflow tract or pulmonary artery: pathophysiologic, diagnostic, and management considerations. Catheter Cardiovasc Interv 2015;86:438-52.

211. Wang Y, Ma C, Yang J, Gu T. Incomplete excision or postoperative hematoma: primary right ventricular intramyocardial lipoma involving the right ventricular outflow tract. J Med Ultrason (2001) 2015;42:541-5

212. Abu Saleh WK, Lin CH, Reardon MJ, Ramlawi B. Right ventricular outflow tract obstruction caused by isolated sinus of Valsalva aneurysm. Texas Heart Inst J 2016;43:357-9.

213. Caldeira CC, Sayad D, Strosberg J, et al. Surgical treatment of an isolated metastatic myocardial neuroendocrine tumor. Ann Thorac Surg 2016;101:747-9.

214. Demirel M, Acar E, Toprak C. Case images: significant obstruction of right outflow tract caused by double-chambered right ventricle. Turk Kardiyol Dern Ars 2016;44:274.

215. Higashi H, Inaba S, Izutani H, Sumimoto T. An unusual cause of lifethreatening right-sided heart failure: undifferentiated pleomorphic sarcoma in the right ventricular outflow tract. Eur Heart J 2016;37:1002.

216. Kim HY, Baek SH, Yoon JU, et al. Cardiac arrest during radical nephrectomy due to a mass in the right ventricular outflow tract. J Clin Anesth 2016;33:156-9.

217. Musuku SR, Devejian N, Pani S, Kassel K. Biventricular outflow trac obstruction after a Rastelli repair. Anesth Analg 2016;122:1305-8. discussion 1308 . 
218. Naqvi SY, Henry D, Furukawa S, Haber H. Primary neuroendocrine tumour of the right ventricle presenting with heart failure and cyanosis. BMJ Case Rep 2016;2016:bcr2016214810.

219. Rao PA, Nagendra Prakash SN, Vasudev S, et al. A rare case of right ventricular myxoma causing recurrent stroke. Indian Heart J 2016;68 (suppl 2):S97-101.

220. Schneider AE, Delaney JW, Cabalka AK. Non-infectious thrombosis of the melody $\left({ }^{\circledR}\right)$ valve: a tale of two cities. Catheter Cardiovasc Interv 2016;88:600-4.

221. Singh A, Sharma R, Garg A, et al. Usefulness of bubble study in echocardiographic diagnosis of contained rupture of hydatid cyst in the right ventricular outflow tract. Echocardiography 2016;33:1402-8.

222. Zhang HW, Zhong MH, Meng W, et al. Intramuscular lipoma as an unusual cause of right ventricular outflow tract obstruction. Echocardiography 2016;33:328-9.

223. Antoniucci ME, Colizzi C, Arlotta G, et al. Dynamic right ventricular outflow obstruction: a rare cause of hypotension during anestesia induction. Int J Surg Case Rep 2017;41:30-2.

224. Joseph G, Chacko ST, Joseph E, Chandra Kumar V. Percutaneous palliation of right ventricular outflow tract obstruction caused by metastatic malignancy. JACC Cardiovasc Interv 2017;10:e79-80.

225. Manmadhan A, Malhotra SP, Weinberg CR, et al. Intimal spindle cell sarcoma masquerading as adult-onset symptomatic pulmonic stenosis: a case report and review of the literature. J Cardiothorac Surg 2017;12:93.

226. Padilla-Ibarra J, Rodriguez Zanella H, Cano Zarate R, AlexandersonRosas E. An unexpected tumor causing right ventricular obstruction. Echocardiography 2017;34:947-8.

227. Privitera F, Monte IP, Indelicato A, Tamburino C. A membranous septal aneurysm causing right ventricular outflow tract obstruction in an adult. J Cardiovasc Echogr 2017;27:145-8.

228. Unosawa S, Osaka S, Arimoto M, et al. Surgical treatment for doublechambered right ventricle in a septuagenarian. Asian Cardiovasc Thorac Ann 2017;25:531-3.

229. Verhoeven PA, Learn CP, Brown NM, Goldstein BH. Noninfective transcatheter pulmonary valve thrombosis: a rare cause of post-implantation pulmonary valve obstruction. JACC Cardiovasc Interv 2017;10: e119-22.

230. Young AM, Danter MR, Lewis Jr. JS, Barton BR. Right ventricular hemangioma in the outflow tract: a rare cause of obstruction. Ann Thorac Surg 2017;103:e245-6.

231. Gangahanumaiah S, Scarr BC, Buckland MR, et al. Suicide right ventricle after lung transplantation for pulmonary vascular disease. J Card Surg 2018;33:412-5.

232. Gendera K, Ewert P, Eicken A. Percutaneous retrieval of a partially flared Melody valve. Cardiol Young 2018;28:753-5.

233. Isom N, Rali AS, Damjanov I, et al. Right ventricular heart failure from a cardiac yolk sac tumor. Am J Case Rep 2018;19:229-33.

234. Karabag T, Arslan C, Yakisan T, Vatan A, Sak D. Metastatic adenocarcinoma involving the right ventricle and pulmonary artery leading to right heart failure: case report. Sao Paulo Med J 2018;136:262-5.

235. Kellermair J, Gitter R, Mair R, et al. First report of an acute, obstructive thrombosis of a Melody valve used for transcatheter pulmonary replacement. Can J Cardiol 2018;34:1688. e13-5.

236. Kocabas U, Zekican G, Vaiz G, Ozbek N, Conkbayir C. Syncope and right-sided heart failure due to right ventricular outflow tract obstruction by giant sinus of Valsalva aneurysm. Cardiology J 2018;25:281-2.
237. Tomar M, Bhan A. Rapidly progressing giant aneurysm of right ventricular outflow tract with severe conduit obstruction: report of two cases. Images Paediatr Cardiol 2018;20:1-7.

238. Zheng MJ, Yang J, He GB, Zhou XD, Liu LW. Percutaneous radiofrequency ablation of obstructive right ventricular giant myxoma. Ann Thorac Surg 2018;105:e159-61.

239. Akikwala T, Trivedi D, Kochamba G, et al. Perioperative evaluation and surgical management of a patient with a pericardial hemangioma abutting the right ventricular outflow tract and main pulmonary artery. J Cardiothorac Vasc Anesth 2019;33:1362-6.

240. Briosa EGA, Dimarco A, Adam R, Haydock P, Flett A. Subtotal obstruction of the right ventricular outflow tract caused by isolated intracardiac renal cell carcinoma metastasis. Circ Cardiovasc Imaging 2019;12:e009714.

241. Mohan JC, Baba BA, Mohan V, Shukla M. Isolated right ventricular outflow obstruction: a unique phenotype of hypertrophic cardiomyopathy with review of literature. IHJ Cardiovasc Case Rep (CVCR) 2019;3:13-7.

242. Munirathinam GK, Kajal K, Jayant A, Dogra N, Singh H. Epicardial echocardiography as rescue modality for detection of dynamic right ventricular outflow tract obstruction in post pulmonary valve stenosis repair. A A Pract 2019;13:396-8.

243. Ramnath NWM, Ozdemir HI, Soliman-Hamad MA. A case of right ventricular outflow tract obstruction after minimally invasive aortic valve replacement. J Card Surg 2019;34:626-7.

244. Serban AM, Batrana N, Cocoi M, et al. The role of echocardiography in the diagnosis and management of a giant unruptured sinus of Valsalva aneurysm. Med Ultrason 2019;21:194-6.

245. Zhu Y, Cohen JE, Ma M, Woo YJ. Redo valve-sparing root replacement for delayed cusp derangement from ventricular septal defect. Ann Thorac Surg 2019;108:e295-6.

246. Zivkovic I, Micovic S, Kecmanovic V, et al. Calcified amorphous tumor of the right ventricular outflow tract. J Card Surg 2019;34:45-6.

247. Prijic S, Buchhorn R. Mechanisms of beta-blockers action in patients with heart failure. Rev Recent Clin Trials 2014;9:58-60.

248. Braunwald E. Mechanism of action of calcium-channel-blocking agents. N Engl J Med 1982;307:1618-27.

249. Galas JM, van der Velde ME, Chiravuri SD, et al. Echocardiographic diagnosis of right ventricular inflow compression associated with pectus excavatum during spinal fusion in prone position. Congenit Heart Dis 2009;4:193-5.

250. Neira VM, Gardin L, Ryan G, et al. A transesophageal echocardiography examination clarifies the cause of cardiovascular collapse during scoliosis surgery in a child. Can J Anesth 2011;58:451-5.

251. Denault A, Vegas A, Lamarche Y, Tardif J, Couture P. Basic Transesophageal and Critical Care Ultrasound. New York: Taylor and Francis, CRC Press; 2018.

252. Denault AY, Couture P, Vegas A, Buithieu J, Tardif JC. Transesophageal Echocardiography Multimedia Manual, 2nd ed: A Perioperative Transdisciplinary Approach. New York: Informa Healthcare; 2011.

\section{Supplementary Material}

To access the supplementary material accompanying this article, visit CJC Open at https://www.cjcopen.ca/ and at doi:10.1016/j.cjco.2021.03.011. 